Atmos. Chem. Phys., 19, 14933-14947, 2019

https://doi.org/10.5194/acp-19-14933-2019

(C) Author(s) 2019. This work is distributed under

the Creative Commons Attribution 4.0 License.

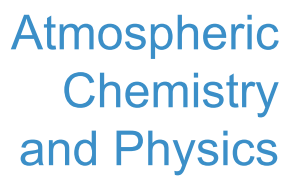

(c) (P)

\title{
Observations of highly oxidized molecules and particle nucleation in the atmosphere of Beijing
}

\author{
James Brean $^{1}$, Roy M. Harrison ${ }^{1, \text { a }}$,Zongbo Shi ${ }^{1}$, David C. S. Beddows ${ }^{1}$, W. Joe F. Acton ${ }^{2}$, C. Nicholas Hewitt ${ }^{2}$, \\ Freya A. Squires ${ }^{3}$, and James Lee ${ }^{3}$ \\ ${ }^{1}$ Division of Environmental Health and Risk Management, School of Geography, Earth and Environmental Sciences, \\ University of Birmingham, Edgbaston, Birmingham B15 2TT, UK \\ ${ }^{2}$ Lancaster Environment Centre, Lancaster University, Lancaster LA1 4YQ, UK \\ ${ }^{3}$ National Centre for Atmospheric Science, Wolfson Atmospheric Chemistry Laboratories, \\ University of York, York YO10 5DD, UK \\ aalso at: Department of Environmental Sciences/Center of Excellence in Environmental Studies, \\ King Abdulaziz University, P.O. Box 80203, Jeddah, 21589, Saudi Arabia
}

Correspondence: Roy M. Harrison (r.m.harrison@bham.ac.uk)

Received: 14 February 2019 - Discussion started: 27 March 2019

Revised: 15 October 2019 - Accepted: 29 October 2019 - Published: 10 December 2019

\begin{abstract}
Particle nucleation is one of the main sources of atmospheric particulate matter by number, with new particles having great relevance for human health and climate. Highly oxidized multifunctional organic molecules (HOMs) have been recently identified as key constituents in the growth and, sometimes, in initial formation of new particles. While there have been many studies of HOMs in atmospheric chambers, flow tubes, and clean environments, analyses of data from polluted environments are scarce. Here, measurements of HOMs and particle size distributions down to small molecular clusters are presented alongside volatile organic compounds (VOCs) and trace-gas data from a campaign in June 2017, in Beijing. Many gas-phase HOMs have been characterized and their temporal trends and behaviours analysed in the context of new particle formation. The HOMs identified have a degree of oxidation comparable to that seen in other, cleaner, environments, likely due to an interplay between the higher temperatures facilitating rapid hydrogen abstractions and the higher concentrations of $\mathrm{NO}_{x}$ and other $\mathrm{RO}_{2}^{*}$ terminators ending the autoxidation sequence more rapidly. Our data indicate that alkylbenzenes, monoterpenes, and isoprene are important precursor VOCs for HOMs in Beijing. Many of the $\mathrm{C}_{5}$ and $\mathrm{C}_{10}$ compounds derived from isoprene and monoterpenes have a slightly greater degree of average oxidation state of carbon compared to those from other precursors. Most HOMs except for large dimers have daytime peak
\end{abstract}

concentrations, indicating the importance of $\mathrm{OH}^{\bullet}$ chemistry in the formation of HOMs, as $\mathrm{O}_{3}$ tends to be lower on days with higher HOM concentrations; similarly, VOC concentrations are lower on the days with higher HOM concentrations. The daytime peaks of HOMs coincide with the growth of freshly formed new particles, and their initial formation coincides with the peak in sulfuric acid vapours, suggesting that the nucleation process is sulfuric-acid-dependent, with HOMs contributing to subsequent particle growth.

\section{Introduction}

Atmospheric particle nucleation, or the formation of solid or liquid particles from vapour-phase precursors, is one of the dominant sources of global aerosol by number, with primary emissions typically dominating the mass loadings (Tomasi et al., 2017). New particle formation (NPF) or the secondary formation of fresh particles is a two-step process comprising initial homogeneous nucleation of thermodynamically stable clusters and their subsequent growth. The rate of growth needs be fast enough to outcompete the loss of these particles by coagulation and condensation processes in order for the new particles to grow, and hence NPF is a function of the competition between source and sink (Gong et al., 2010). New particle formation has been shown to occur across a 
wide range of environments (Kulmala et al., 2005). The high particle load in urban environments was thought to suppress new particle formation until measurements in the early 2000s (McMurry et al., 2000; Shi et al., 2001; Alam et al., 2003), with frequent occurrences observed even in the most polluted urban centres. NPF events in Beijing occur on about $40 \%$ of days annually, with the highest rates in the spring (Wu et al., 2007, 2008; Wang et al., 2016). Chu et al. (2019) review many studies of NPF which have taken place in China and highlight the need for long-term observations and mechanistic studies.

NPF can lead to the production of cloud condensation nuclei (CCN) (Wiedensohler et al., 2009; Yu and Luo, 2009; Yue et al., 2011; Kerminen et al., 2012), which influences the radiative atmospheric forcing (Penner et al., 2011). A high particle count, such as that caused by nucleation events, has been shown to precede haze events in environments such as Beijing (Guo et al., 2014). These events are detrimental to health and quality of life. The sub- $100 \mathrm{~nm}$ fraction of particles to which new particle formation contributes is often referred to as the ultrafine fraction. Ultrafine particles (UFPs) pose risks to human health due to their high number concentration. UFPs exhibit gas-like behaviour and enter all parts of the lung before penetrating the bloodstream (Miller et al., 2017). They can initiate inflammation via oxidative stress responses, progressing conditions such as atherosclerosis and initiating cardiovascular responses such as hypertension and myocardial infarction (Delfino et al., 2005; Brook et al., 2010).

Highly oxidized multifunctional molecules (HOMs), organic molecules with $\mathrm{O}: \mathrm{C}$ ratios $>0.6$, are the result of atmospheric autoxidation and have recently been subject to much investigation, in part because the extremely low volatilities arising from their high $\mathrm{O}: \mathrm{C}$ ratios favour their condensation into the particulate phase. HOMs are most well characterized as the product of oxidation of the biogenic monoterpenoid compound $\alpha$-pinene (Riccobono et al., 2014; Tröstl et al., 2016; Bianchi et al., 2017). Although globally biogenic volatile organic compound (BVOC) concentrations far exceed anthropogenic volatile organic compound (AVOC) concentrations, in the urban environment the anthropogenic fraction is far more significant. Formation of HOMs from aromatic compounds has been demonstrated in laboratory studies and these have been hypothesized to be large drivers of NPF in urban environments (Wang et al., 2017; Molteni et al., 2018; Qi et al., 2018). The formation of HOMs through autoxidation processes begins with the reaction of VOCs with $\mathrm{OH}^{*}, \mathrm{O}_{3}$, or $\mathrm{NO}_{3}^{*}$; formation of a peroxy radical $\left(\mathrm{RO}_{2}^{*}\right)$ is followed by rapid $\mathrm{O}_{2}$ additions and intramolecular hydrogen abstractions (Jokinen et al., 2014; Rissanen et al., 2014; Kurtén et al., 2015). Furthermore, generation of oligomers from stabilized Criegee intermediates arising from short-chain alkenes has been hypothesized as a contributor of extremely low-volatility organic compounds (ELVOCs) and low-volatility organic compounds (LVOCs)
(Zhao et al., 2015). The low volatilities of these molecules arise from their numerous oxygen-containing functionalities, and this allows them to make a significant contribution to early stage particle growth where other species cannot due to the Kelvin effect (Tröstl et al., 2016), although the contribution of HOMs to the initial molecular clusters is still debated (Kurtén et al., 2016; Elm et al., 2017; Myllys et al., 2017).

Recent technological advances have facilitated insights into the very first steps of nucleation, which were previously unseen, with mass spectrometric techniques such as the atmospheric-pressure-interface time-of-flight mass spectrometer (APi-ToF-MS) and its chemical ionization counterpart (CI-APi-ToF-MS) allowing for high-mass and hightime-resolution measurements of low-volatility compounds and molecular clusters. Diethylene glycol-based particle counters, such as the particle size magnifier (PSM), allow for measurements of particle size distributions down to the smallest molecular clusters nearing $1 \mathrm{~nm}$. Recent chamber studies have elucidated the contribution of individual species to particle nucleation, ammonia, and amines, greatly enhancing the rate of sulfuric acid nucleation (Kirkby et al., 2011; Almeida et al., 2013). In these studies, HOMs have been identified, formed through autoxidation mechanisms (Schobesberger et al., 2013; Riccobono et al., 2014; Ehn et al., 2014). These are key to early particle growth (Tröstl et al., 2016) and can nucleate even in the absence of sulfuric acid in chambers (Kirkby et al., 2016) and in the free troposphere (Rose et al., 2018). In this paper, we report the results of HOM and particle size measurements during a summer campaign in Beijing, China.

\section{Data and methods}

\subsection{Sampling site}

Sampling was performed as part of the Air Pollution and Human Health in a Developing Megacity (APHH-Beijing) campaign, a large international collaborative project examining emissions, processes, and health effects of air pollution. For a comprehensive overview of the programme, see Shi et al. (2019). All sampling was conducted across a 1-month period at the Institute for Atmospheric Physics (IAP), Chinese Academy of Sciences, Beijing ( $\left.39^{\circ} 58.53^{\prime} \mathrm{N}, 116^{\circ} 22.69^{\prime} \mathrm{E}\right)$. The sampling was conducted from a shipping container, with sampling inlets $1-2 \mathrm{~m}$ above ground level, the nearest road being $30 \mathrm{~m}$ away. Meteorological parameters (wind speed, wind direction, relative humidity (RH), and temperature) were measured at the IAP meteorological tower, $20 \mathrm{~m}$ away from the sampling site, $30 \mathrm{~m}$ from the nearest road at a height of $120 \mathrm{~m}$. Data were continuously taken from the CI-APiToF-MS during a 2-week period, but due to data losses only $5 \mathrm{~d}$ of data are presented here. Particle size distribution measurements were taken during a $33 \mathrm{~d}$ period from 24 May to 26 June 2017. 


\subsection{Chemical ionization atmospheric-pressure-interface time-of-flight mass spectrometry}

The Aerodyne nitrate chemical ionization atmosphericpressure-interface time-of-flight mass spectrometer (CI-APiToF-MS) was used to make measurements of neutral oxidized organic compounds, sulfuric acid, and their molecular clusters at high time resolution with high resolving power. The ionization system charges molecules by adduct formation, such as in the case of organic compounds with two or more hydrogen bond donor groups (Hyttinen et al., 2015), or proton transfer in the case of strong acids like sulfuric acid. Hydroxyl or hydroperoxyl functionalities are both common hydrogen-bond-donating groups, with hydroperoxyl being the more efficient hydrogen bond donor (Møller et al., 2017). This instrument has been explained in great detail elsewhere (Junninen et al., 2010; Jokinen et al., 2012), but briefly the front end consists of a chemical ionization system where a $10 \mathrm{~L} \mathrm{~min}^{-1}$ sample flow is drawn in through the $1 \mathrm{~m}$ long 1 in. OD stainless-steel tubing opening. A secondary flow was run parallel and concentric to this sample flow, rendering the reaction chamber effectively wall-less. A $3 \mathrm{~cm}^{3} \mathrm{~min}^{-1}$ flow of a carrier gas $\left(\mathrm{N}_{2}\right)$ is passed over a reservoir of liquid $\mathrm{HNO}_{3}$, entraining vapour, which is subsequently ionized to $\mathrm{NO}_{3}^{-}$via an $\mathrm{X}$-ray source. This flow is then guided into the sample flow. The nitrate ions will then charge molecules by either clustering or proton transfer. The mixed flows travelling at $10 \mathrm{~L} \mathrm{~min}^{-1}$ enter the critical orifice at the front end of the instrument at $0.8 \mathrm{~L} \mathrm{~min}^{-1}$ and are guided through a series of differentially pumped chambers before reaching the ToF analyser. Two of these chambers contain quadrupoles, which can be used to select greater sensitivity for certain mass ranges, and the voltages across each individual chamber can be tuned to maximize sensitivity and resolution for ions of interest. Mass spectra are taken at a frequency of $20 \mathrm{kHz}$ but are recorded at a rate of $1 \mathrm{~Hz}$. All data analysis was carried out in the Tofware package in Igor Pro 6 (Tofwerk AG, Switzerland). A seven-point mass calibration was performed for every minute of data, and all data were normalized to signal at 62,80 , and $125 \mathrm{~m} / Q$ to account for fluctuations in ion signal, these masses representing $\mathrm{NO}_{3}^{-}, \mathrm{H}_{2} \mathrm{ONO}_{3}^{-}$, and $\mathrm{HNO}_{3} \mathrm{NO}_{3}^{-}$ respectively. Typical values for calibration coefficients range from $10^{9}$ to $10^{10}$ molec. $\mathrm{cm}^{-3}$ from these normalized data (Kürten et al., 2012), producing peak sulfuric acid concentrations in the range of $10^{6}$ molec. $\mathrm{cm}^{-3}$. From the very limited periods with simultaneous data for $\mathrm{SO}_{2}, \mathrm{OH}$ radical, and condensation sink, it was possible to calculate $\mathrm{H}_{2} \mathrm{SO}_{4}$ concentrations of $10^{3}$ to $10^{5}$ molec. $\mathrm{cm}^{-3}$, in which range the calibration constant was $7.0 \pm 1.6 \times 10^{8} \mathrm{~cm}^{-3}$, which fits well with that expected for this concentration range (Kürten et al., 2012). The nitrate-water cluster is included as the presence of many nitrate-water clusters of the general formula $\left(\mathrm{H}_{2} \mathrm{O}\right)_{x}\left(\mathrm{HNO}_{3}\right)_{y} \mathrm{NO}_{3}^{-}$were found, where $x=(1,2,3, \ldots 20)$ and $y=(0,1)$. No sensitivity calibration was performed for these measurements, and so all values are reported in normalized signal intensity. Due to the high resolving power of the CI-APi-ToF-MS system (mass resolving power of $3500 \mathrm{~m} / \Delta \mathrm{m}$ and mass accuracy of $20 \mathrm{ppm}$ at $288 \mathrm{~m} / \mathrm{Q}$; resolving power is measured as the mass/charge, termed $m$ divided by the peak width at its half maximum, dubbed $\Delta m$ ), multiple peaks can be fit at the same unit mass and their molecular formulae assigned. These peaks follow the general formula $\mathrm{C}_{x} \mathrm{H}_{y} \mathrm{O}_{z} \mathrm{~N}_{w}$, where $x=2-20, y=2-32, z=4$ 16 , and $w=0-2$, spanning from small organic acids like oxalic and malonic acid through to large dimers of oxidized monoterpene $\mathrm{RO}_{2}^{*}$ radicals such as $\mathrm{C}_{20} \mathrm{H}_{31} \mathrm{O}_{9} \mathrm{~N}$. Beyond $500 \mathrm{~m} / Q$, peak fitting and assignment of compositions becomes problematic as signal decreases, mass accuracy decreases, and the total number of chemical compositions increases, so peaks above the $\mathrm{C}_{20}$ region have not been assigned, and a number of peaks have been unassigned due to this uncertainty (Cubison and Jimenez, 2015). As proton transfer mostly happens with acids, and nearly all HOM molecules will be charged by adduct formation, it is possible to infer the uncharged formula; therefore all HOMs from here onwards will be listed as their uncharged form.

\subsection{Size distribution measurements}

Two scanning mobility particle sizer (SMPS) instruments measured particle size distributions at $15 \mathrm{~min}$ time resolution, with one long SMPS (TSI 3080 EC, 3082 long DMA, 3775 CPC, TSI, USA) and one nano SMPS (3082 EC, 3082 nano DMA, 3776 CPC, TSI, USA) measuring the ranges $14-615$ and $4-65 \mathrm{~nm}$ respectively. A particle size magnifier (A10, Airmodus, FN) linked to a CPC (3775, TSI, USA) measured the sub- $3 \mathrm{~nm}$ size fraction. The PSM was run in stepping mode, operating at four different saturator flows to vary the lowest size cut-off of particles that it will grow (this cut-off is technically a point of $50 \%$ detection efficiency) of $<1.30,1.36,1.67$, and $2.01 \mathrm{~nm}$. The instrument switched between saturator flows per $2.5 \mathrm{~min}$, giving a sub$2.01 \mathrm{~nm}$ size distribution every $10 \mathrm{~min}$. The data were treated with a moving-average filter to account for jumps in total particle count, and due to the similar behaviour of the two upper and two lower size cuts, these have been averaged to two size cuts at 1.30 and $1.84 \mathrm{~nm}$.

\subsection{Calculations}

The condensation sink (CS) was calculated from the size distribution data as follows:

$\mathrm{CS}=4 \pi D \sum_{d^{\prime} \mathrm{p}} \beta_{m, d_{\mathrm{p}}^{\prime}} d^{\prime}{ }_{\mathrm{p}} N_{d^{\prime} \mathrm{p}}$,

where $D$ is the diffusion coefficient of the diffusing vapour (assumed sulfuric acid), $\beta_{m}$ is a transition regime correction (Kulmala et al., 2012), $d_{\mathrm{p}}^{\prime}$ is particle diameter, and $N_{d_{\mathrm{p}}^{\prime}}$ is the number of particles at diameter $d_{\mathrm{p}}^{\prime}$. 


\subsection{Other measurements}

Measurements of the classical air pollutants were measured at the same site and have been reported in the campaign overview paper (Shi et al., 2019). $\mathrm{SO}_{2}$ was measured using a $43 \mathrm{i} \mathrm{SO}_{2}$ analyser (Thermo Fisher Scientific, USA), $\mathrm{O}_{3}$ with a 49i $\mathrm{O}_{3}$ analyser (Thermo Fisher Scientific, USA), and $\mathrm{NO}_{x}$ with a 42i-TL trace $\mathrm{NO}_{x}$ analyser (Thermo Fisher Scientific, USA) and a T500U CAPS $\mathrm{NO}_{2}$ analyser (Teledyne API, USA). VOC mixing ratios were measured using a proton-transfer-reaction time-of-flight mass spectrometer (PTR-ToF-MS 2000, Ionicon, Austria).

\section{Results and discussion}

\subsection{Characteristics of sampling period}

A total of $5 \mathrm{~d}$ of CI-API-ToF-MS data were collected successfully, from 21 June 2017 midday through 26 June 2017 midday. New particle formation events were observed on 24 June in the late afternoon and 25 June at midday. Some nighttime formation of molecular clusters was seen earlier in the campaign, as were several peaks in the $1.5-100 \mathrm{~nm}$ size range, likely from pollutant plumes containing freshly nucleating condensable materials. The trace gases, $\mathrm{O}_{3}, \mathrm{SO}_{2}$, $\mathrm{NO}$, and $\mathrm{NO}_{2}$, are plotted in Fig. $\mathrm{S} 1$ in the Supplement. $\mathrm{O}_{3}$ shows mid-afternoon peaks, around $\sim 120 \mathrm{ppb}$ on the first $2 \mathrm{~d}$ of the campaign and 50-70 ppb for the later days. $\mathrm{SO}_{2}$ shows a large peak, reaching $4 \mathrm{ppb}$ on 22 June but $<1 \mathrm{ppb}$ for the rest of campaign. NO shows strong mid-morning rush-hourrelated peaks, declining towards midday due to being rapidly consumed by $\mathrm{O}_{3}$. $\mathrm{NO}_{2}$ shows large traffic-related peaks. The sulfuric acid signal across this period as measured by $\mathrm{NO}_{3}^{-}$ CI-APi-ToF-MS showed strong midday peaks, with the highest signal on 24 and 25 June 2017. The meteorological data are shown in Fig. S2 alongside condensation sink (CS). The conditions were generally warm and humid, with temperature reaching its maximum on 25 June 2017, with a peak hourly temperature of $31^{\circ} \mathrm{C}$. High temperatures were also seen on 21 and 24 June, 30 and $26^{\circ} \mathrm{C}$ respectively.

\subsection{Gas-phase HOM chemistry}

\subsubsection{Bulk chemical properties}

For the peaks that have had chemical formulae assigned, oxidation state of carbon, or $\mathrm{OS}_{\mathrm{c}}$, can be used to describe their bulk oxidation chemistry. $\mathrm{OS}_{\mathrm{c}}$ is defined as (Kroll et al., 2011)

$\mathrm{OS}_{\mathrm{c}}=(2 \times \mathrm{O}: \mathrm{C})-\mathrm{H}: \mathrm{C}$.

This does not account for the presence of nitrate ester groups, which has been accounted for previously by subtracting 5 times the $\mathrm{N}$ : C ratio (Massoli et al., 2018), under the assumption that all nitrogen-containing functionality is in the form of nitrate ester $\left(\mathrm{RONO}_{2}\right)$ groups. In Beijing, multiple sources of nitrate-containing organic compounds are seen, in the forms of amines, nitriles, and heterocycles. The variation in oxidation state with carbon number $\left(\mathrm{C}_{n}\right)$ without correction for nitrate esters is plotted in Fig. 1. The average oxidation state of carbon in this dataset tends to decrease with an increase in $\mathrm{C}_{n}$, highest where $\mathrm{C}_{n}=5$, attributable to both high $\mathrm{O}: \mathrm{C}$ and peak area, for the peak assigned to $\mathrm{C}_{5} \mathrm{H}_{10} \mathrm{~N}_{2} \mathrm{O}_{8}$ at $m / Q 288 . \mathrm{C}_{n}=5$ also shows the greatest distribution of oxidation states, likely due to the high ambient concentration of isoprene and therefore its many oxidation products being of high enough signal for many well-resolved peaks to be seen in this dataset. It is worth noting that some of the ions plotted here may not form through peroxy radical autoxidation, such as $\mathrm{C}_{5} \mathrm{H}_{10} \mathrm{~N}_{2} \mathrm{O}_{8}$, which may be a second-generation oxidation product of isoprene under high $\mathrm{NO}_{x}$ (Lee et al., 2016). $\mathrm{C}_{n}=10$ and 15 also see a small increase in average oxidation number compared to their neighbours. The lower oxidation state of the larger products is likely a function of two things. First and foremost, any autoxidation mechanism must undergo more steps in order for a larger molecule to reach an $\mathrm{O}: \mathrm{C}$ ratio equivalent to that of a smaller one, and the equivalent $\mathrm{O}: \mathrm{C}$ ratio is ultimately less likely to be reached before the radical is terminated (Massoli et al., 2018). Secondly, the lower vapour pressures of these larger products will lead to their partitioning into the condensed phase more readily than the smaller; thus they are more rapidly lost (Mutzel et al., 2015).

The degrees of OSc observed here are similar to those seen in other environments such as during the SOAS campaign in 2013 in the southern United States, characterized by low $\mathrm{NO} / \mathrm{NO}_{2}$ and high temperatures, where campaign averages of $0.3 \mathrm{ppb}, 0.4-0.5 \mathrm{ppb}$, and $25^{\circ} \mathrm{C}$ respectively were measured, although an additional parameter to account for nitrogen-containing VOCs is included in the calculation (Massoli et al., 2018). The $\mathrm{OS}_{\mathrm{c}}$ observed in Beijing is also higher than that seen in the boreal forest environment of Hyytiälä, despite extremely low $\mathrm{NO}_{x}$ concentrations, likely due to low temperature conditions dominating in those conditions (Schobesberger et al., 2013). These degrees of oxidation relatively similar to those seen in other, cleaner environments are likely due to an interplay between the higher temperatures facilitating rapid hydrogen abstractions (Crounse et al., 2013; Quéléver et al., 2019) and the higher concentrations of $\mathrm{NO}_{x}, \mathrm{HO}_{2}^{*}$, and other $\mathrm{RO}_{2}^{*}$ molecules terminating the autoxidation sequence more efficiently (Praske et al., 2018; Rissanen, 2018; Garmash et al., 2019).

A mass defect plot is shown in Fig. 2, which shows nominal mass plotted against mass defect for all peaks in this dataset. Mass defect is defined as the ion mass minus integer mass. This is shown for two separate daytime periods, one where nucleation was not occurring and HOM concentrations are lower (10:30-12:00 CST 23 June 2017) and one where nucleation was occurring under high HOM concentrations (10:30-12:00 CST 25 June 2017). The band of 


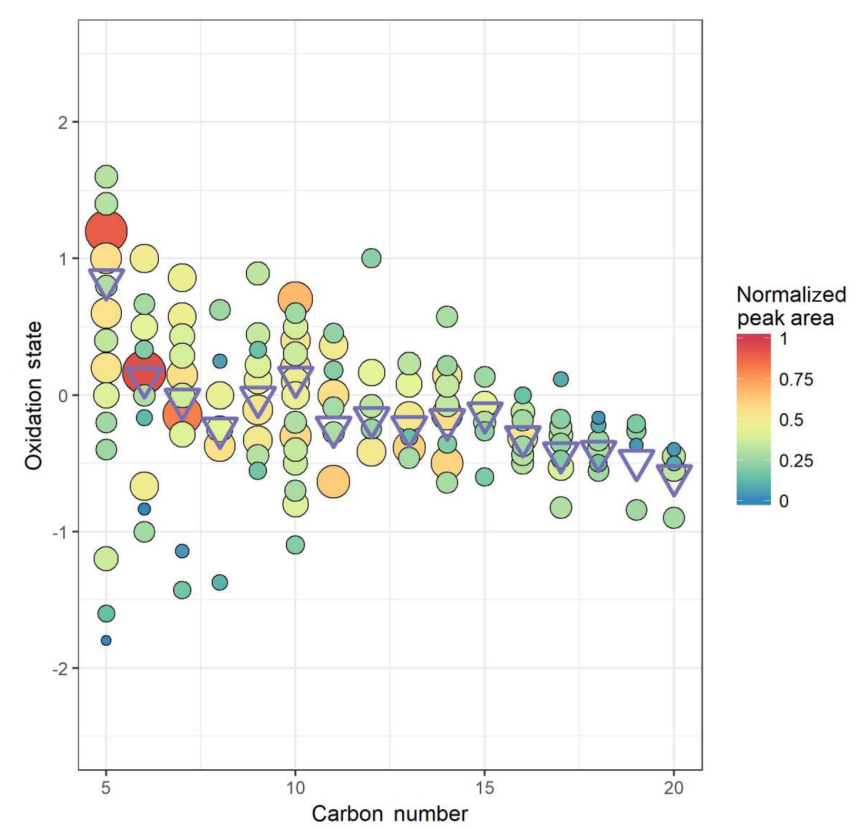

Figure 1. Oxidation state of carbon calculated as 2 times the oxygen-to-carbon ratio minus the hydrogen-to-carbon ratio against carbon number for (coloured) individual ions and (blue circles) signal-weighted average for each carbon number. Area and colour are both proportional to the peak area for each ion.

lower mass defect is characterized by a number of large peaks with high signal, for example, at $m / Q 436$ the ion $\left(\mathrm{C}_{2} \mathrm{H}_{7} \mathrm{~N}\right)_{2}\left(\mathrm{H}_{2} \mathrm{SO}_{4}\right)_{2} \mathrm{HSO}_{4}^{-}$. The upper component of the mass defect is dominated by organic compounds, and the upper end of the more positive mass defect is occupied by molecules with more ${ }^{1} \mathrm{H}$ (mass defect $7.825 \mathrm{mDa}$ ) and ${ }^{14} \mathrm{~N}$ (mass defect $3.074 \mathrm{mDa}$ ). The end of the less positive mass defect has lower ${ }^{1} \mathrm{H}$ and more ${ }^{16} \mathrm{O}$ (mass defect $-5.085 \mathrm{mDa}$ ); alternatively put, the mass defect reflects the variation in $\mathrm{OS}_{\mathrm{c}}$. The organic components with more positive mass defects will be more volatile than their lower mass defect counterparts as they will contain fewer oxygen functionalities (Tröstl et al., 2016; Stolzenburg et al., 2018). These higher-volatility products may still contribute to larger size particle growth. The more negative mass defect components will be those of greater $\mathrm{O}: \mathrm{C}$ and therefore lower volatility, LVOCs, and the yet larger and more oxidized components, ELVOCs (Tröstl et al., 2016). During the nucleation period, the signal intensity for the species in the upper band of more negative mass defect have the most marked increase in concentration, with significantly less difference $>500 \mathrm{~m} / Q$. This region 200-400 m/Q will contain most of the $>\mathrm{C}_{5}$ monomer HOMs seen in this dataset.

\subsubsection{Diurnal trends of HOMs}

Temporal trends of HOMs in the urban atmosphere can reveal their sources and behaviour in the atmosphere. Most of the HOM species peak in the daytime. These species all follow a similar diurnal trend, as shown in Fig. 3. The concentrations of both $\mathrm{O}_{3}$ and $\mathrm{OH}^{*}$ are high during the summer period in Beijing (although the nitrate chemical ionization technique is not sensitive to all $\mathrm{OH}^{*}$ oxidation products; Berndt et al., 2015). Figure S1 shows the time series of concentrations of NO, which is considered a dominant peroxy radical terminator of particular importance in the polluted urban environment (Khan et al., 2015). Radicals such as $\mathrm{HO}_{2}^{*}$ and $\mathrm{RO}_{2}^{*}$ also typically peak during daytime. The HOM components peaking in the daytime are presumed to be the oxidation products of a mixture of anthropogenic and biogenic components, such as alkylbenzenes, monoterpenes, and isoprene. The oxidation of monoterpenes, specifically the monoterpene $\alpha$-pinene, has been the subject of extensive study recently, with the $\mathrm{O}_{3}$-initiated autoxidation sequence being the best characterized (Ehn et al., 2014; Jokinen et al., 2014; Kurtén et al., 2015; Kirkby et al., 2016); ozonolysis of $\alpha$-pinene opens the ring structure and produces a $\mathrm{RO}_{2}^{*}$ radical (Kirkby et al., 2016). In the case of aromatics, $\mathrm{OH}^{*}$ addition to the ring and the subsequently formed bicyclic peroxy radical are the basis for the autoxidation of compounds such as xylenes and trimethylbenzenes (Molteni et al., 2018; Wu et al., 2017).

The identified compounds have been roughly separated into several categories, each of these plotted in Fig. 3. Figure $3 \mathrm{a}$ shows the separation of components into nonnitrogen-containing HOMs and nitrogen-containing HOMs, or organonitrates (ONs). The ON signal is much higher than that of the HOM, attributable in part to a few ions of high signal, such as the isoprene organonitrate $\mathrm{C}_{5} \mathrm{H}_{10} \mathrm{~N}_{2} \mathrm{O}_{8}$. A few similar structural formulae are seen $\left(\mathrm{C}_{5} \mathrm{H}_{10} \mathrm{~N}_{2} \mathrm{O}_{6}\right.$, $\mathrm{C}_{5} \mathrm{H}_{11} \mathrm{NO}_{6}, \mathrm{C}_{5} \mathrm{H}_{11} \mathrm{NO}_{7}$, etc.), some of which have been identified as important gas-phase oxidation products of isoprene under high- $\mathrm{NO}_{x}$ conditions (Xiong et al., 2015), and their contribution to secondary organic aerosol (SOA) has been explored previously (Lee et al., 2016). A high nitrophenol signal is also seen, $\mathrm{C}_{6} \mathrm{H}_{5} \mathrm{NO}_{3}$. The signal for $\mathrm{HOM}$ compounds is less dominated by a few large ions. The prevalence of $\mathrm{ON}$ compounds points towards the important role of $\mathrm{NO}_{x}$ as a peroxy radical terminator, with the probability of the $\mathrm{RO}_{2}^{*}+\mathrm{NO}_{x}$ reaction producing nitrate ester compounds increasing with the size of the $\mathrm{RO}_{2}^{*}$ molecule (Atkinson et al., 1982). The $\mathrm{NO}_{x}$ concentrations in urban Beijing are approximately a factor of 10 higher than seen at the Hyytiälä station in Finland as reported by Yan et al. (2016), and hence it is expected to be a more significant peroxy radical terminator.

Despite the very large fluxes of anthropogenic organic pollutants in Beijing, biogenic emissions are still an important source of reactive VOCs in the city, with abundant isoprene oxidation products observed (see above), as well as monoter- 

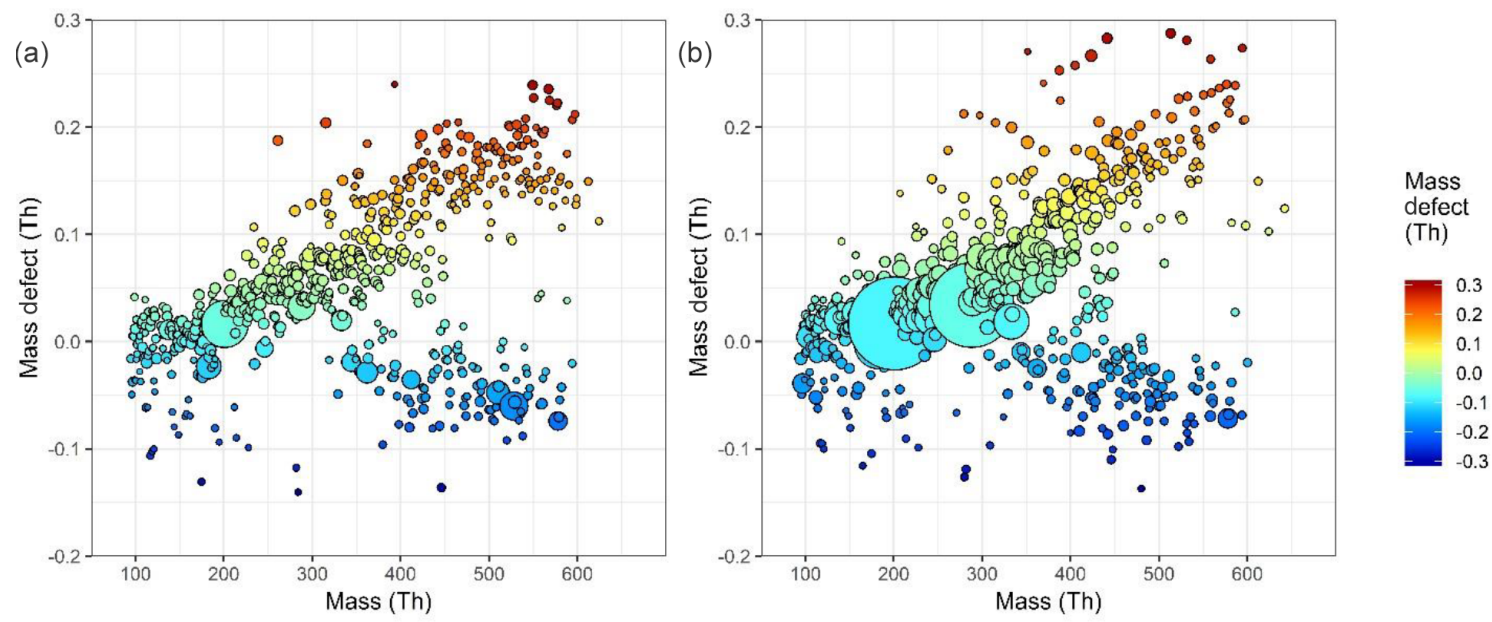

Figure 2. Mass defect plot of fitted mass spectral peaks between 100 and 600 mass units at (a) 10:30-12:00 CST on 23 June 2017, a nonnucleation day, and (b) at 10:30-12:00 CST on 25 June 2017, a nucleation day. Mass defect can be defined as the mass - integer mass. The size of point is proportional to the signal intensity. As ${ }^{1} \mathrm{H}$ has a positive mass defect (1.007276 Da), the upward trend along the horizontal indicates increasing carbon chain length, and differences at similar masses are due to increasing oxygen functionality and clustering with species such as sulfuric acid (negative mass defect) and ammonia (positive mass defect), as ${ }^{16} \mathrm{O}$ and ${ }^{32} \mathrm{~S}$ have negative mass defects (15.9949 and $31.9721 \mathrm{Da}$ respectively), while ${ }^{14} \mathrm{~N}$ has a positive mass defect at $14.0031 \mathrm{Da}$. The two large peaks seen at 201 and $288 \mathrm{~m} / Q$ are the nitrophenol-nitrate cluster and $\mathrm{C}_{5} \mathrm{H}_{10} \mathrm{~N}_{2} \mathrm{O}_{8}$-nitrate cluster respectively.

pene monomers $\left(\mathrm{C}_{10} \mathrm{H}_{16} \mathrm{O}_{9}, \mathrm{C}_{10} \mathrm{H}_{15} \mathrm{O}_{9} \mathrm{~N}\right)$ and some dimer products $\left(\mathrm{C}_{20} \mathrm{H}_{30} \mathrm{O}_{11}, \mathrm{C}_{20} \mathrm{H}_{31} \mathrm{O}_{11} \mathrm{~N}\right)$. The time series of the signals of all $\mathrm{C}_{5}, \mathrm{C}_{10}$, and $\mathrm{C}_{20}$ molecules is plotted in Fig. 3b, with $\mathrm{C}_{5}$ species assumed to be isoprene-dominated and $\mathrm{C}_{10}$ and $\mathrm{C}_{20}$ assumed to be monoterpene-dominated. Signals for isoprene oxidation products are higher, with abundant isoprene nitrate and dinitrate products. $\mathrm{C}_{10}$ products show similar behaviour, with, for example, several $\mathrm{C}_{10} \mathrm{H}_{15} \mathrm{O}_{x} \mathrm{~N} x=5$ 9 compounds seen. The $\mathrm{C}_{20}$ signal intensities are low and follow the general formula $\mathrm{C}_{20} \mathrm{H}_{x} \mathrm{O}_{\mathrm{y}} \mathrm{N}_{\mathrm{z}}$, where $x=26-32$, $y=7-11$, and $z=0-2$; in Fig. 3 the signal for $\mathrm{C}_{20}$ compounds has been multiplied by a factor of 50 for visibility. The low signals reflect the lack of $\mathrm{RO}_{2}^{*}$ cross reactions necessary for the production of these accretion products.

Other identified peaks are plotted in Fig. $3 \mathrm{c}$. The $\mathrm{C}_{2}-\mathrm{C}_{4}$ components are summed together, these being small organic acids such as malonic acid and oxalic acid, as well as products such as $\mathrm{C}_{4} \mathrm{H}_{7} \mathrm{O}_{6} \mathrm{~N}$. Malonic acid is the most prominent here, seen as both an $\mathrm{NO}_{3}^{-}$adduct $\left(\mathrm{C}_{3} \mathrm{H}_{4} \mathrm{O}_{4} \mathrm{NO}_{3}^{-}\right)$and a proton transfer product $\left(\mathrm{C}_{3} \mathrm{H}_{3} \mathrm{O}_{4}^{-}\right)$at a ratio of around $2: 3$. Measurements of particle-phase dicarboxylic acids in cities typically show greater concentrations of oxalic acid than malonic acid (Ho et al., 2010), and these acids are primarily produced in the aqueous phase (Bikkina et al., 2014). Primary sources of dicarboxylic acid include fossil fuel combustion (Kawamura and Kaplan, 1987) and biomass burning (Narukawa et al., 1999), which are both plentiful in urban Beijing. The $\mathrm{C}_{6}-$ $\mathrm{C}_{9}$ components are assumed to be dominated by oxidation products of alkylbenzenes such as $\mathrm{C}_{8} \mathrm{H}_{12} \mathrm{O}_{5}$, although fragments of other compounds, i.e. monoterpenes, can also oc- cupy this region (Isaacman-Vanwertz et al., 2018). It is assumed the majority of the signal for these peaks come from alkylbenzenes. This assumption is supported by the relative signal intensity ratios of the oxygen numbers of monomer $\mathrm{C}_{8} \mathrm{H}_{12} \mathrm{O}_{n}$ compounds being similar to those seen for $\mathrm{xy}$ lene oxidation products in previous work (Molteni et al., 2018). The largest fraction, $C_{11}$ through $C_{18}$, includes the larger compounds, oxidation products of larger aromatics, or products of the cross reaction of smaller $\mathrm{RO}_{2}^{*}$ radicals. Here they are grouped without more sophisticated disaggregation as they all follow much the same time series, with species such as $\mathrm{C}_{11} \mathrm{H}_{11} \mathrm{O}_{8} \mathrm{~N}$ following the same temporal trends as $\mathrm{C}_{15} \mathrm{H}_{16} \mathrm{O}_{9}$ and $\mathrm{C}_{16} \mathrm{H}_{24} \mathrm{O}_{12}$.

Nearly all ions with the exception of the larger compounds attributed to the cross reaction of $\mathrm{C}_{10}$ monomers follow similar temporal patterns, with the majority of peaks occurring in the daytime. This reflects the importance of the concentration of atmospheric oxidants. Some selected oxidation products are plotted against their precursor VOCs in Fig. 4. The concentration of isoprene is plotted against the signal of a nitrate $\mathrm{HOM}$ product, $\mathrm{C}_{5} \mathrm{H}_{9} \mathrm{NO}_{6}$ (Xiong et al., 2015; Lee et al., 2016), while monoterpenes are plotted against $\mathrm{C}_{10} \mathrm{H}_{16} \mathrm{O}_{9}$ (Ehn et al., 2014; Berndt et al., 2016; Yan et al., 2016; Kirkby et al., 2016; Massoli et al., 2018) and $\mathrm{C}_{2}$ benzenes against $\mathrm{C}_{8} \mathrm{H}_{12} \mathrm{O}_{6}$ (Molteni et al., 2018; Wang et al., 2017). The first half of the time series shows little correlation between the VOC species and the resultant oxidation products, while isoprene, monoterpenes, and $\mathrm{C}_{2}$ benzenes follow their usual diurnal cycles, with isoprene having the most distinct cycle with a strong midday peak. The last $2 \mathrm{~d}$, however, show sim- 
(a)

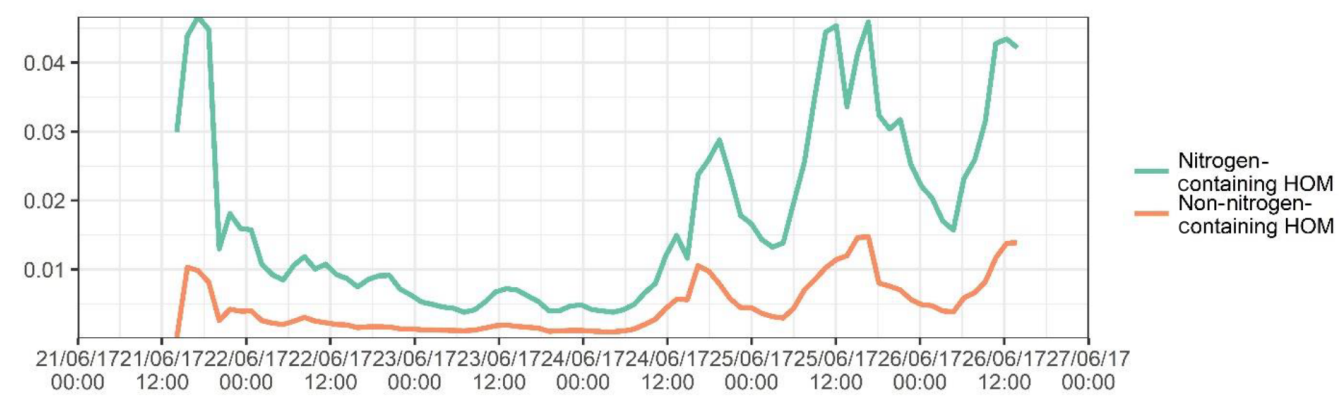

(b)

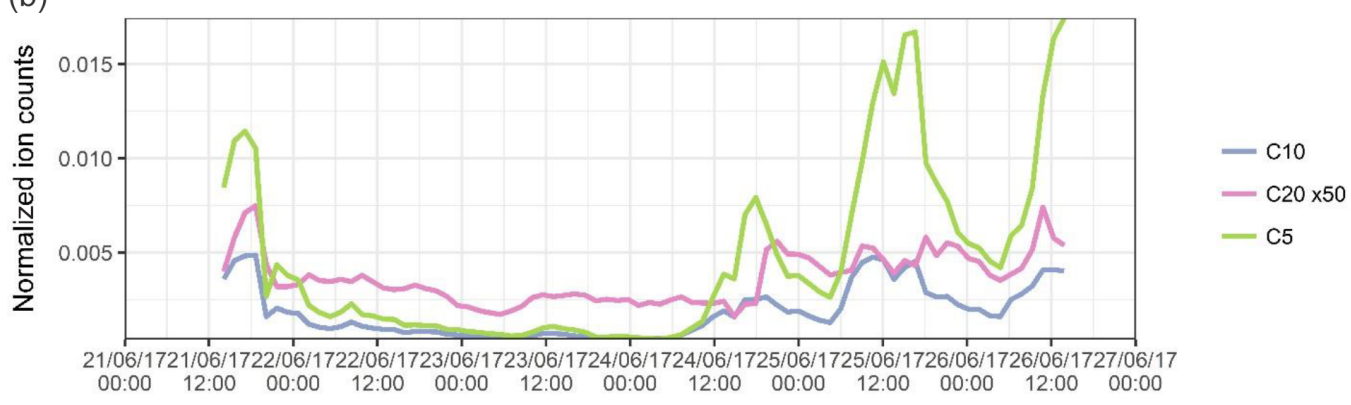

(c)

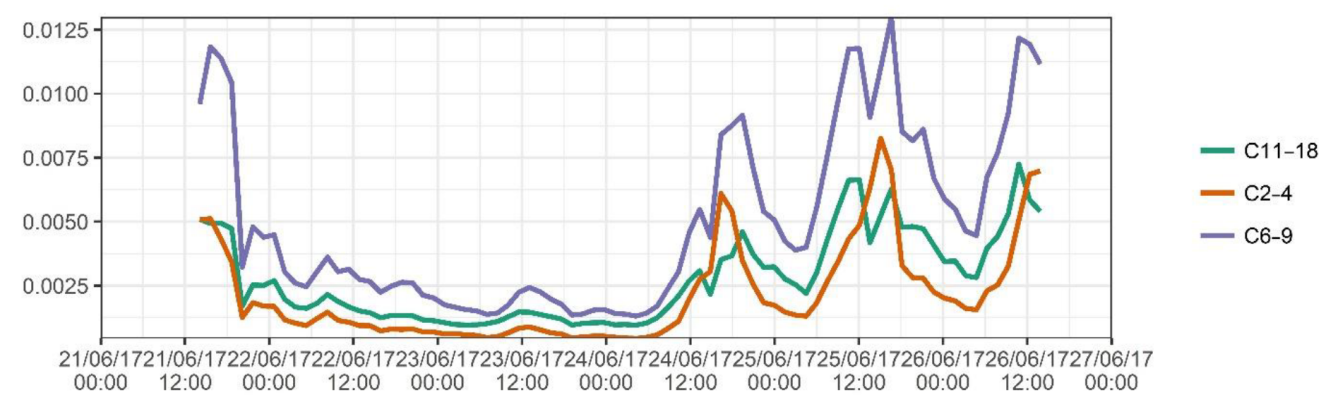

Figure 3. Summed time series of the normalized signals of (a) all non-nitrogen-containing HOMs and all organonitrates identified; (b) $\mathrm{C}_{5}$, $\mathrm{C}_{10}$, and $\mathrm{C}_{20}$ components, assumed to be dominated by isoprene, monoterpene monomer, and monoterpene dimers, and signal for $\mathrm{C}_{20}$ multiplied 50 times to fit scale; and (c) summed $\mathrm{C}_{6}-\mathrm{C}_{9}$ components and summed $\mathrm{C}_{11}-\mathrm{C}_{18}$ components, assumed to be dominated by alkylbenzenes and other larger components respectively.

ilar and coinciding peaks in both the VOCs and HOMs HOMs show afternoon peaks on both days and an initial shelf on the final half day. The $\mathrm{C}_{5} \mathrm{H}_{9} \mathrm{NO}_{6}$ peak follows some of the peaks of the isoprene, but not all (e.g. morning shelf of isoprene on 24 June). Concentrations of isoprene do not seem to determine directly the signal of HOM, as the day with the lowest isoprene of all is the day with the highest $\mathrm{C}_{5} \mathrm{H}_{9} \mathrm{NO}_{6}$. The $\mathrm{C}_{10} \mathrm{H}_{16} \mathrm{O}_{9}$ trace also has coincidental peaks with the monoterpene trace, including two $4 \mathrm{~h}$ separated simultaneous peaks on 25 June. The peaks in the concentrations of $\mathrm{C}_{2}$ benzenes are nearly synchronous with the peaks in $\mathrm{C}_{8} \mathrm{H}_{12} \mathrm{O}_{6}$, for which the data exhibit a strong mid-afternoon peak likely due to the lack of an efficient ozonolysis reaction pathway; the main oxidant of $\mathrm{C}_{2}$ benzenes is the $\mathrm{OH}^{*}$ radical. Trends of both $C_{3}$ benzenes and their HOMs are much the same as $C_{2}$ benzenes as discussed above, pointing to similar sources and oxidation chemistries. The concentration of precursor VOC is likely a driving force in the identity and quantity of various HOM products, but not the sole determinant, as while there are simultaneous peaks of VOCs and HOMs, both the condensation sink and oxidant concentrations also influence HOM product signals.

The first half of campaign measurements are marked by an episode of low HOM signals. A diurnal cycle still exists but it is weak. The radiation intensity was significantly lower on these prior days than it was on 24 June. No data are available for the final period of measurement. Ozone is higher on the prior measurement days with lower HOM signals (see Fig. S1). Little agreement is seen between VOC concentration and HOM signals on these days. The condensational sinks are roughly similar to those on days of higher HOM concentrations, but temperature and solar radi- 


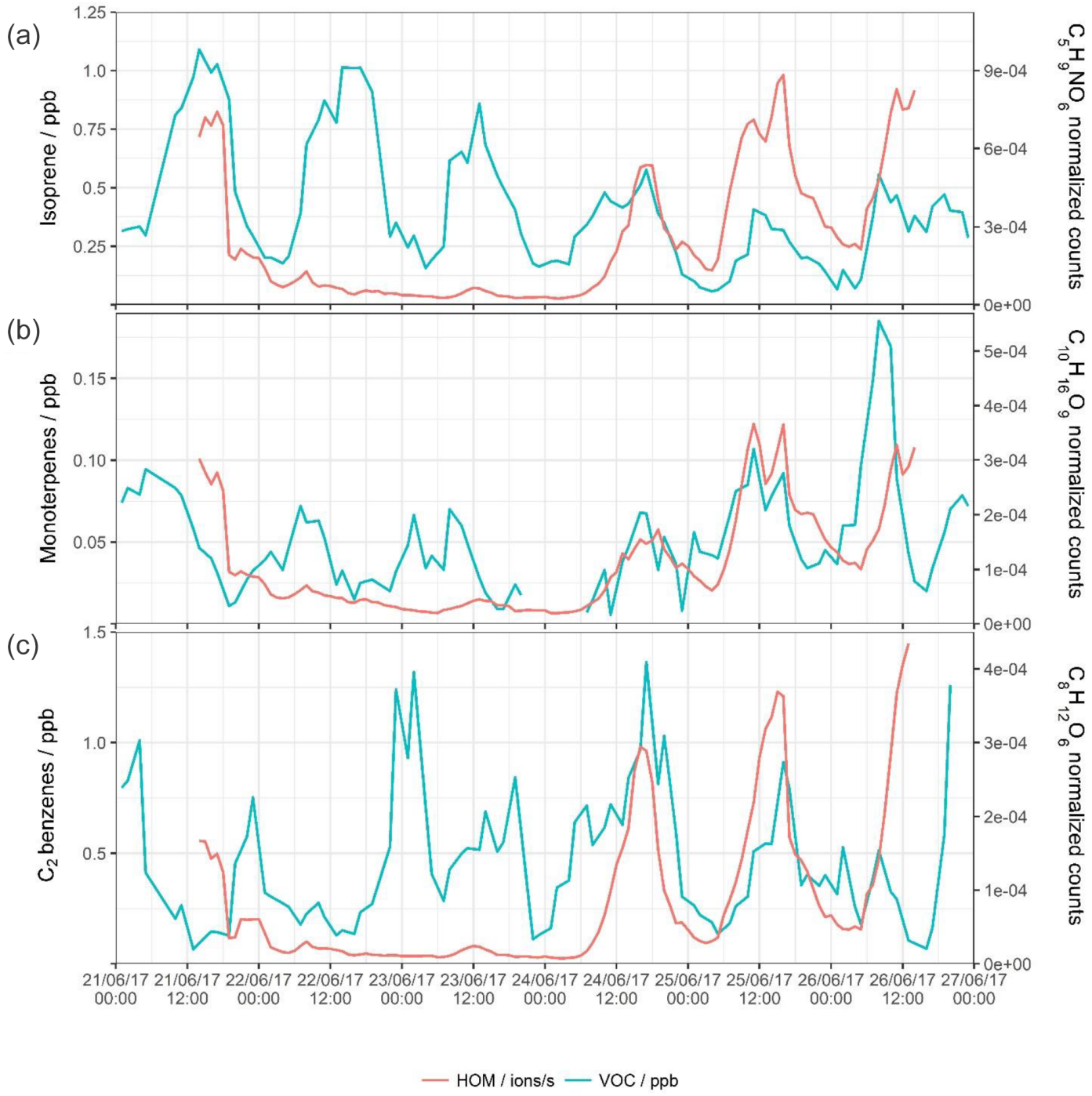

Figure 4. Time series for the whole sampling campaign for the concentrations of (left axis) VOCs as measured by PTR-ToF-MS and (right axis) a selected HOM product associated with that precursor.

ation are much lower. HOM formation is largely dependent upon VOC concentration, oxidant concentration (which will be lower if solar radiation is lower, especially in the case of $\mathrm{OH}^{*}$, the main oxidant of aromatic species especially), and temperature (as $\mathrm{H}$ shifts are highly temperature-dependent) (Quéléver et al., 2019), as well as losses by $\mathrm{RO}_{2}^{*}$ termination before a molecule can become HOM and losses to condensational sink. The low HOM concentration is likely due to these lower temperatures and weaker solar radiation not facilitating HOM formation.

The $\mathrm{C}_{20}$ compounds plotted in Fig. $3 \mathrm{~b}$ show no strong diurnal sequence, contrasting with other HOMs. We can presume that all $\mathrm{C}_{20}$ compounds identified are the result of the reaction of two monoterpenoid $\mathrm{C}_{10} \mathrm{RO}_{2}^{-}$radicals, a reasonable assumption as all identified $\mathrm{C}_{20}$ species follow the general formula outlined for these reactions $\left(\mathrm{C}_{20} \mathrm{H}_{28-32} \mathrm{O}_{6-16}\right)$.
The formation of $\mathrm{C}_{20}$ dimers is dependent upon two processes, initial oxidation of monoterpenes and $\mathrm{RO}_{2}-\mathrm{RO}_{2}$ termination. Initial oxidation is contingent upon oxidant concentration, which is highest in the daytime, and $\mathrm{RO}_{2}^{*}-\mathrm{RO}_{2}^{*}$ termination is contingent upon the probability of the molecular collision between the $\mathrm{RO}_{2}^{*}$ molecules occurring before other radical termination (i.e. $\mathrm{RO}_{2}^{-}-\mathrm{NO}_{x}$ or $\mathrm{RO}_{2}^{-}-\mathrm{HO}_{2}^{*}$ ). There is likely a strong diurnal sequence in the dominant $\mathrm{RO}_{2}^{*}$ termination mechanisms across the daytime period, and the combination of the two factors discussed above results in there being no strong diurnal trend in these molecules. A lower oxidant concentration at night results in fewer $\mathrm{RO}_{2}^{*}$ molecules, but less $\mathrm{NO}$ and $\mathrm{HO}_{2}^{*}$ results in a greater chance for those $\mathrm{RO}_{2}^{-}$molecules to dimerise (Rissanen, 2018; Garmash et al., 2019). As the levels of $\mathrm{NO}_{x}$ in Beijing fall, the peroxy radical termination reactions will be less probable 
compared to continued autoxidation (Praske et al., 2018), and it is expected that more oxidized HOM products will be seen with lower volatilities and therefore a greater potential contribution to earlier stage particle formation and growth.

\subsection{New particle formation}

Nearly all the signal intensity in the CI-APi-ToF-MS instrument arises from molecules charged by $\mathrm{NO}_{3}^{-}$; therefore plotting the unit mass resolution data (the data gained by integrating over the entire area at each $m / Q$ integer) against time simply describes the evolution of oxidized organic molecules, acids, and their molecular clusters with both each other and stabilizing amine species. This is done in Fig. 5. As the signal intensity varies by factors of 10 from mass to mass, each value has been normalized so they have maxima at 1 . This has been done separately for $2 \mathrm{~d}$ for clarity, as the signal intensity also varies from day to day. PSM data for these $2 \mathrm{~d}$ is also plotted in Fig. 5, with both total particle count $>1.30 \mathrm{~nm}$ in black and the number difference between the lower and upper size cuts $(1.30$ and $1.84 \mathrm{~nm})$ in blue, which shows the number of particles between these sizes. The relationship between mass and electrical mobility diameter can be defined thus (Tammet, 1995)

$d_{\mathrm{e}}=\left(\frac{6 m}{\pi \rho}\right)^{\frac{1}{3}}+d_{\mathrm{g}}$

where $d_{\mathrm{e}}$ is the electrical mobility diameter of the cluster or particle, $m$ is the mass of the cluster or particle expressed in kilogrammes, $\rho$ is the density, and $d_{\mathrm{g}}$ is the effective gas diameter, determined to be $0.3 \mathrm{~nm}$ for smaller particles (Larriba et al., 2011). We can use this to draw a comparison between the PSM and CI-APi-ToF-MS measurements. If a density of $1.2 \mathrm{~g} \mathrm{~cm}^{-3}$ is assumed, then once molecular clusters reach the $>400 \mathrm{~m} / Q$ range, they will be seen in the lowest size cut of the PSM, or $>700 \mathrm{~m} / Q$ if a density of $2.0 \mathrm{~g} \mathrm{~cm}^{-3}$ is assumed. A full table of densities is provided in the Supplement.

A burst in the signal seen by the CI-APi-ToF-MS occurs first in the late morning in Fig. 5a, and this is at the same time as peaks begin to rise in the identified HOMs (see Fig. 3). Here, the PSM is not available due to an instrumental fault until 16:00 CST; however, at that point, an elevation to particle count and a large elevation to cluster count can be seen. Moving into the evening period, the mass contour shows peaks in larger masses $>400 \mathrm{~m} / Q$. These are likely dimerized compounds and products of $\mathrm{NO}_{3}^{*}$ chemistry with little contribution to newly forming particles but still sensitive to chemical ionization by $\mathrm{NO}_{3}^{-}$. Many of these peaks cannot be assigned due to uncertainties in the structural formula assignment for higher mass peaks, as the number of possible dimerized compounds is many, being the combination of most possible $\mathrm{RO}_{2}$ radicals. Graphically, these are over-represented in Fig. 5 due to the normalization, and their signals (especially $>500 \mathrm{~m} / \mathrm{Q}$ ) are much lower than the signals $<400 \mathrm{~m} / Q$.
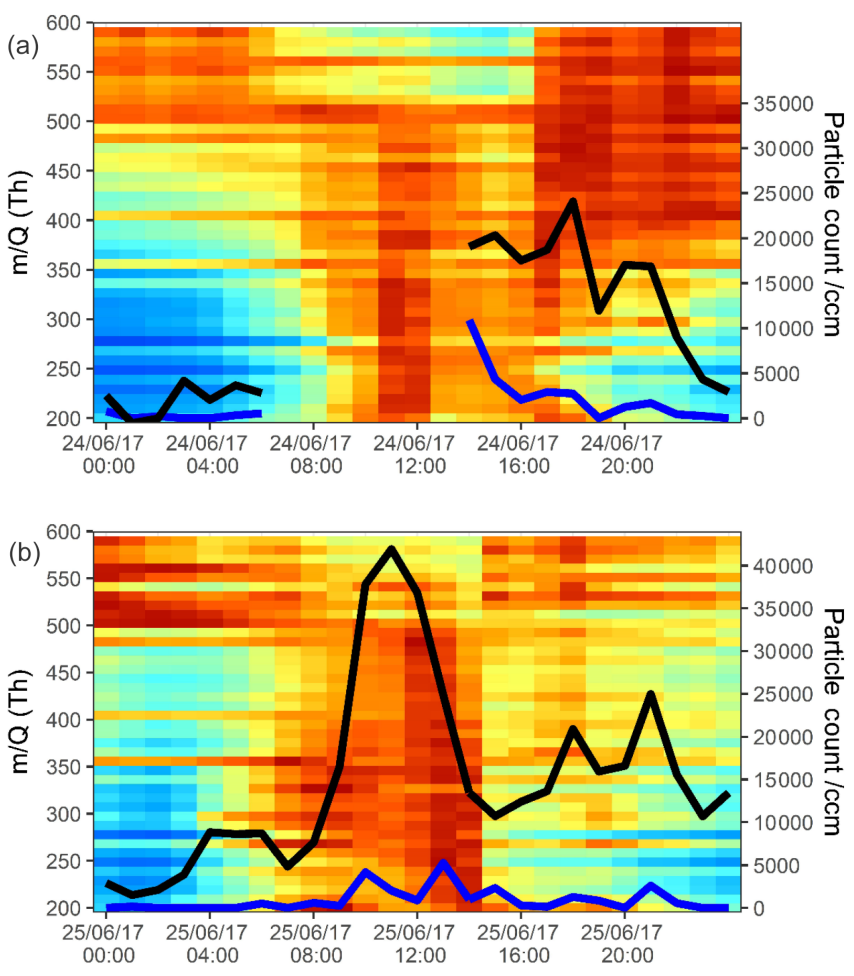

- Cluster count Particle number

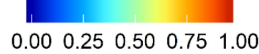

Figure 5. Normalized unit mass $\mathrm{NO}_{3}^{-} \mathrm{CI}-\mathrm{APi}-\mathrm{ToF}-\mathrm{MS}$ signal intensity on 24 June 2017 (a) and 25 June 2017 (b). Each individual unit mass was normalized to a maximum of 1 . Each period is normalized separately so the individual signal maxima on each day are visible. The graph is plotted between 200 and 600 mass units, with every 10 mass units averaged for simplicity. On the secondary axis PSM data are plotted, both total particle count $>1.30 \mathrm{~nm}$ (black trace) and total clusters between 1.30 and $1.84 \mathrm{~nm}$ (blue trace). Data are plotted at $1 \mathrm{~h}$ time resolution.

The second day plotted in Fig. 5b (25 June 2017) shows a strong afternoon peak to the HOMs (for most HOMs, stronger than that on the day prior). Particle formation is shown in the PSM data. A strong midday peak to particle number is seen with two distinct peaks in cluster count. These two peaks are not coincidental with the two peaks in HOM signal (i.e. nitrogen-containing HOMs in Fig. 3a peaking at 11:00 and 16:00 CST). Sulfuric acid, however, does peak synchronously with the particle number count. Sulfuric acid is plotted across the contour plot in Fig. 6, where PSM data are also shown in the bottom panel. The peak in CIAPi-ToF-MS mass signal, visible in Fig. 5, occurs at around 12:00-13:00 CST; peaks in the PSM cluster count occur at 10:00 and 13:00 CST. Peaks in mass up to $550 \mathrm{~m} / Q$ are seen in the CI-APi-ToF-MS at 13:00 CST. Assuming the density of these species is $\leq 1.6 \mathrm{~g} \mathrm{~cm}^{-3}$, then these will be suitably sized to be grown in the PSM saturator. These newly formed 

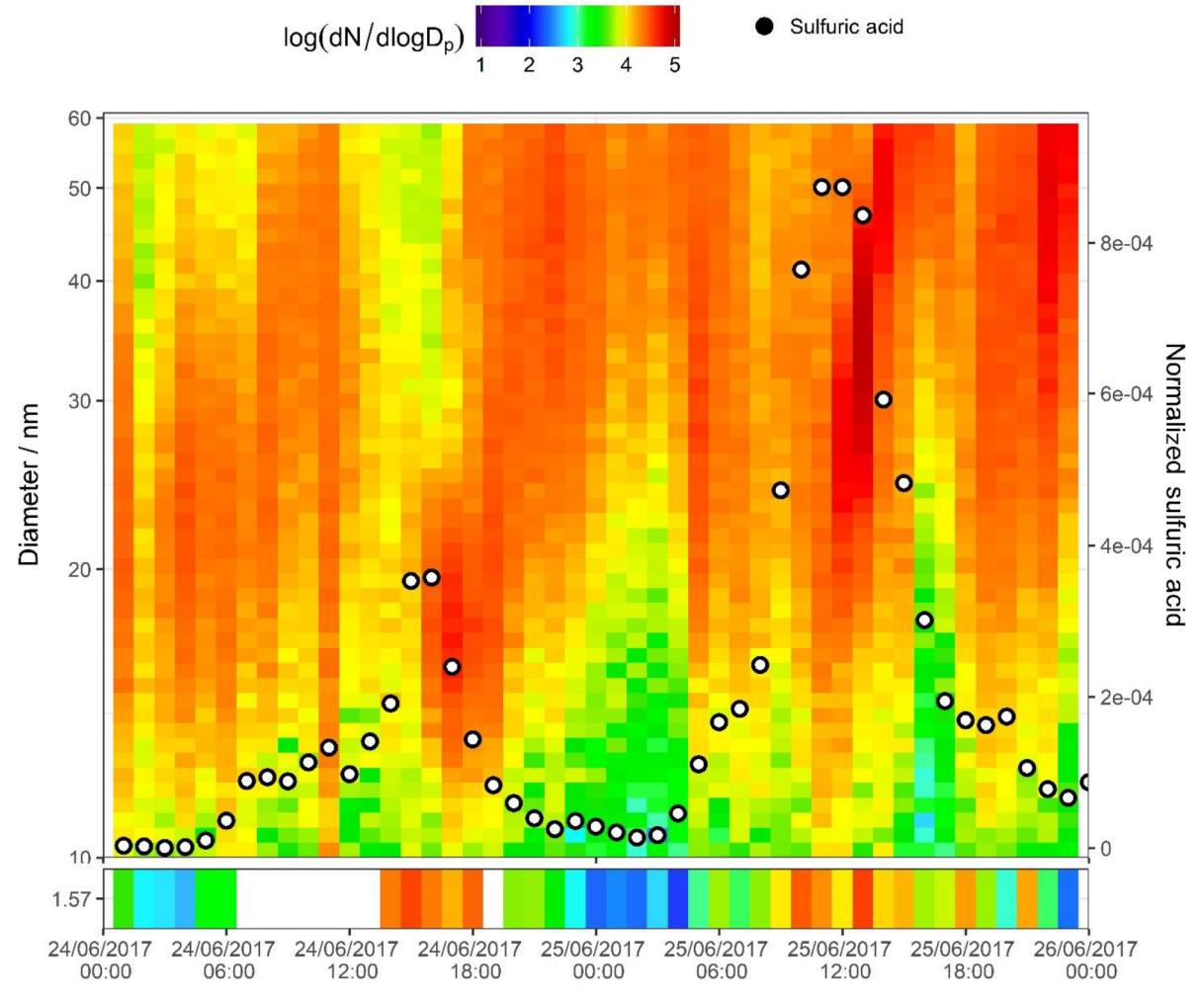

Figure 6. SMPS + PSM contour plot for two nucleation days on 24 and 25 June 2017. Data in the bottom panel are from the PSM instrument, and the top panel from the nano SMPS; units in the colour bar $\operatorname{are} \log _{10}\left(\mathrm{~d} N / \log D_{\mathrm{p}}\right)$ for $N$ in reciprocal cubic centimetres. Points signify normalized sulfuric acid concentration (right axis) as measured by CI-APi-ToF-MS.

particles then go on to grow and contribute significantly to the larger particle count (Fig. S3). As initial particle formation coincides with sulfuric acid signal peaks and before HOM signals peak, it can be assumed on these days that the HOM contribution to the initial particle formation is modest.

There is recent strong evidence to suggest that the driving force of the earliest stages of particle formation in urban Shanghai is sulfuric acid and $\mathrm{C}_{2}$ amines (Yao et al., 2018), and the coincidental peaks of sulfuric acid with new particles as seen in Fig. 6 suggest a similar behaviour. Dimethylamine (DMA) can efficiently stabilize the sulfuric acid clusters (Almeida et al., 2013). Here, few larger sulfuric acidDMA clusters were visible in the dataset, as seen in the work by Yao et al. (2018). Although five sulfuric aciddimethylamine (SA-DMA) ions were observed, the others were likely too low in signal to be confidently resolved from their neighbouring peaks; however, clusters of up to four sulfuric acid molecules and three dimethylamine molecules were seen, with similar diurnal trends in sulfuric acid. The scarcity of SA-DMA clusters is likely due to instrumental conditions, rather than their absence in the atmosphere. The nitrate chemical ionization system tends to evaporate amine compounds upon charging, and as specific voltage-tuning setups can lend themselves towards preservation or breakage of molecular clusters, the signal for larger sulfuric acid clusters was also very weak. The formation of HOM-sulfuric acid clusters is unlikely under atmospheric conditions (Elm et al., 2017) and few of these were observed. Signals of HOMs seem to coincide with later particle growth; it can be expected that HOM molecules make a more significant contribution to particle growth than to early particle formation, with the largest and most oxidized being involved in early growth and the smaller and less oxidized contributing to later growth as the necessary vapour pressure properties become less demanding.

\section{Conclusions}

The average degree of HOM oxidation in Beijing is comparable with that seen in other environments. Rapid intramolecular hydrogen shifts during autoxidation due to the higher temperatures are probably offset by the frequent termination reactions due to high $\mathrm{NO}_{x}$ concentrations. $\mathrm{OS}_{\mathrm{c}}$ values seem to be marginally higher for biogenic species.

The temporal trend of nearly every HOM shows afternoon or evening maxima. Both $\mathrm{O}_{3}$ and $\mathrm{OH}^{*}$ have high daytime concentrations, and these likely drive the initial oxidation steps. The species arising from alkylbenzene precursors show sharper afternoon peaks, probably since their oxidation 
is $\mathrm{OH}^{*}$-dominated. Many of the rest of the peaks, coming from largely BVOC precursors, show broader daytime peaks, being influenced by $\mathrm{O}_{3}$ also. There seems to be no direct link between VOC concentrations and HOM signals, with days of lower precursor VOC sometimes having higher HOM signals and vice versa.

Initial particle formation coincides with peak sulfuric acid signals, while the growth of the particles correlates more closely with the signals of HOMs. This is very similar to behaviour observed in a study of NPF in Shanghai which was attributed to sulfuric acid-dimethylamine-water nucleation with condensing organic species contributing to particle growth (Yao et al., 2018), and this is further backed up by numerous SA-DMA clusters present in this dataset. The freshly formed particles grow and contribute significantly to total particle loading. This is visible when the unit mass CI-APiToF-MS data are plotted as a contour plot, and further this is visible in the PSM data, with bursts in both total number count $>1.30 \mathrm{~nm}$ and the number of molecular clusters between 1.30 and $1.84 \mathrm{~nm}$. As $\mathrm{NO}_{x}$ levels fall in Beijing due to traffic emission control measures being enforced, it is likely that autoxidation will become increasingly significant in the new particle formation processes. The number of molecules detected by the $\mathrm{NO}_{3}^{-}$CI-APi-ToF-MS is undoubtedly many more than have had formulae assigned here, but to identify more requires a more sophisticated data deconvolution.

Data availability. Data supporting this publication are openly available from the UBIRA eData repository at https://doi.org/10.25500/edata.bham.00000304 (Brean and Harrison, 2019).

Supplement. The supplement related to this article is available online at: https://doi.org/10.5194/acp-19-14933-2019-supplement.

Author contributions. The study was conceived and planned by RMH and ZS. DCSB and JB set up and operated the main instrumental measurements, and JB prepared the first draft of the paper and responded to comments from RMH and ZS. CNH and WJFA contributed the hydrocarbon data and provided comments on the draft paper, and FAS and JL contributed the gas-phase pollutant data.

Competing interests. The authors declare that they have no conflict of interest.

Special issue statement. This article is part of the special issue "In-depth study of air pollution sources and processes within Beijing and its surrounding region (APHH-Beijing) (ACP/AMT interjournal SI)". It is not associated with a conference.
Acknowledgements. This was part of the APHH-Beijing programme funded by the UK Natural Environmental Research Council, the National Centre for Atmospheric Science, and the Natural Sciences Funding Council of China. We thank Xinming Wang from the Guangzhou Institute of Geochemistry, Chinese Academy of Sciences; Brian Davison from Lancaster University; and Ben Langford, Eiko Nemitz, Neil Mullinger, and other staff from the Centre for Ecology and Hydrology, Edinburgh for assistance with the VOC measurements and associated infrastructure.

Financial support. This research has been supported by the Natural Environmental Research Council (grant no. NE/N007190/1) and the Natural Sciences Funding Council of China. It was additionally facilitated by the National Centre for Atmospheric Science ODA national capability programme ACREW (NE/R000034/1), which is supported by NERC and the GCRF.

Review statement. This paper was edited by Kimitaka Kawamura and reviewed by three anonymous referees.

\section{References}

Alam, A., Shi, J. P., and Harrison R. M.: Observations of new particle formation in urban air, J. Geophys. Res., 108, 4093-4107, https://doi.org/10.1029/2001JD001417, 2003.

Almeida, J., Schobesberger, S., Kürten, A., Ortega, I. K., Kupiainen-Määttä, O., Praplan, A. P., Adamov, A., Amorim, A., Bianchi, F., Breitenlechner, M., David, A., Dommen, J., Donahue, N. M., Downard, A., Dunne, E., Duplissy, J., Ehrhart, S., Flagan, R. C., Franchin, A., Guida, R., Hakala, J., Hansel, A., Heinritzi, M., Henschel, H., Jokinen, T., Junninen, H., Kajos, M., Kangasluoma, J., Keskinen, H., Kupc, A., Kurtén, T., Kvashin, A. N., Laaksonen, A., Lehtipalo, K., Leiminger, M., Leppä, J., Loukonen, V., Makhmutov, V., Mathot, S., McGrath, M. J., Nieminen, T., Olenius, T., Onnela, A., Petäjä, T., Riccobono, F., Riipinen, I., Rissanen, M., Rondo, L., Ruuskanen, T., Santos, F. D., Sarnela, N., Schallhart, S., Schnitzhofer, R., Seinfeld, J. H., Simon, M., Sipilä, M., Stozhkov, Y., Stratmann, F., Tomé, A., Tröstl, J., Tsagkogeorgas, G., Vaattovaara, P., Viisanen, Y., Virtanen, A., Vrtala, A., Wagner, P. E., Weingartner, E., Wex, H., Williamson, C., Wimmer, D., Ye, P., Yli-Juuti, T., Carslaw, K. S., Kulmala, M., Curtius, J., Baltensperger, U., Worsnop, D. R., Vehkamäki, H., and Kirkby, J.: Molecular understanding of sulphuric acid-amine particle nucleation in the atmosphere, Nature, 502, 359-363, 2013.

Atkinson, R., Aschmann, S. M., Carter, W. P. L., Winer, A. M., and Pitts, J. N.: Alkyl nitrate formation from the nitrogen oxide $\left(\mathrm{NO}_{x}\right)$ air photooxidations of $\mathrm{C}_{2}-\mathrm{C}_{8}$ n-alkanes, J. Phys. Chem., 86, 4563-4569, 1982.

Berndt, T., Richters, S., Kaethner, R., Voigtländer, J., Stratmann, F., Sipilä, M., Kulmala, M., and Herrmann, H.: Gas-Phase Ozonolysis of Cycloalkenes: Formation of Highly Oxidized $\mathrm{RO}_{2}$ Radicals and Their Reactions with $\mathrm{NO}, \mathrm{NO}_{2}, \mathrm{SO}_{2}$, and Other $\mathrm{RO}_{2}$ Radicals, J. Phys. Chem. A., 119, 10336-10348, 2015.

Berndt, T., Richters, S., Jokinen, T., Hyttinen, N., Kurtén, T., Otkjær, R. V., Kjaergaard, H. G., Stratmann, F., Herrmann, 
H., Sipilä, M., Kulmala, M., and Ehn, M.: Hydroxyl radicalinduced formation of highly oxidized organic compounds, Nature Comm., 7, 13677, https://doi.org/10.1038/ncomms13677, 2016.

Bianchi, F., Garmash, O., He, X., Yan, C., Iyer, S., Rosendahl, I., Xu, Z., Rissanen, M. P., Riva, M., Taipale, R., Sarnela, N., Petäjä, T., Worsnop, D. R., Kulmala, M., Ehn, M., and Junninen, H.: The role of highly oxygenated molecules (HOMs) in determining the composition of ambient ions in the boreal forest, Atmos. Chem. Phys., 17, 13819-13831, https://doi.org/10.5194/acp-17-138192017, 2017.

Bikkina, S., Kawamura, K., Miyazaki, Y., and Fu, P.: High abundances of oxalic, azelaic, and glyoxylic acids and methylglyoxal in the open ocean with high biological activity: Implication for secondary OA formation from isoprene, Geophys. Res. Lett., 41, 3649-3657, https://doi.org/10.1002/2014GL059913, 2014.

Brean, J. and Harrison, R. M.: HOMS measured by APi-ToF in Beijing, University of Birmingham, https://doi.org/10.25500/edata.bham.00000304, 2019.

Brook, R. D., Rajagopalan, S., Pope, C. A., Brook, J. R., Bhatnagar, A., Diez-Roux, A. V., Holguin, F., Hong, Y., Luepker, R. V., Mittleman, M. A., Peters, A., Siscovick, D., Smith, S. C., Whitsel, L., and Kaufman, J. D.: Particulate matter air pollution and cardiovascular disease: An update to the scientific statement from the american heart association, Circulation, 121, 23312378, 2010.

Chu, B., Kerminen, V.-M., Bianchi, F., Yan, C., Petäjä, T., and Kulmala, M.: Atmospheric new particle formation in China, Atmos. Chem. Phys., 19, 115-138, https://doi.org/10.5194/acp-19-1152019, 2019.

Crounse, J. D., Nielsen, L. B., Jørgensen, S., Kjaergaard, H. G., and Wennberg, P. O.: Autoxidation of organic compounds in the atmosphere, J. Phys. Chem. Lett., 4, 3513-3520, 2013.

Cubison, M. J. and Jimenez, J. L.: Statistical precision of the intensities retrieved from constrained fitting of overlapping peaks in high-resolution mass spectra, Atmos. Meas. Tech., 8, 23332345, https://doi.org/10.5194/amt-8-2333-2015, 2015.

Delfino, R. J., Sioutas, C., and Malik, S.: Potential role of ultrafine particles in associations between airborne particle mass and cardiovascular health, Environ. Health Perspect., 113, 934-946, 2005.

Ehn, M., Thornton, J. A., Kleist, E., Sipilä, M., Junninen, H., Pullinen, I., Springer, M., Rubach, F., Tillmann, R., Lee, B., LopezHilfiker, F., Andres, S., Acir, I.-H., Rissanen, M., Jokinen, T., Schobesberger, S., Kangasluoma, J., Kontkanen, J., Nieminen, T., Kurtén, T., Nielsen,L. B., Jørgensen, S., Kjaergaard, H. G., Canagaratna, M., Maso, M. D., Berndt, T., Petäjä, T., Wahner, A., Kerminen, V.-M., Kulmala, M., Worsnop, D. R., Wildt, J., and Mentel, T. F.: A large source of low-volatility secondary organic aerosol, Nature, 506, 476-479, 2014.

Elm, J., Myllys, N., and Kurtén, T.: What is Required for Highly Oxidized Molecules to Form Clusters with Sulfuric Acid?, J. Phys. Chem. A, 121, 4578-4587, 2017.

Garmash, O., Rissanen, M. P., Pullinen, I., Schmitt, S., Kausiala, O., Tillmann, R., Percival, C., Bannan, T. J., Priestley, M., Hallquist, Å. M., Kleist, E., Kiendler-Scharr, A., Hallquist, M., Berndt, T., McFiggans, G., Wildt, J., Mentel, T., and Ehn, M.: Multigeneration $\mathrm{OH}$ oxidation as a source for highly oxygenated or- ganic molecules from aromatics, Atmos. Chem. Phys. Discuss. https://doi.org/10.5194/acp-2019-582, in review, 2019.

Gong, Y., Hu, M., Cheng, Y., Su, H., Yue, D., Liu, F., Wiedensohler, A., Wang, Z., Kalesse, H., Liu, S., Wu, Z., Xiao, K., Mi, P., and Zhang, Y.: Competition of coagulation sink and source rate: New particle formation in the Pearl River Delta of China, Atmos. Environ., 44, 3278-3285, 2010.

Guo, S., Hu, M., Zamora, M. L., Peng, J., Shang, D., Zheng, J., Du, Z., Wu, Z., Shao, M., Zeng, L., Molina, M. J., and Zhang, R.: Elucidating severe urban haze formation in China, P. Natl. Acad. Sci. USA, 111, 17373-17378, 2014.

Ho, K. F., Lee, S. C., Ho, S. S. H., Kawamura, K., Tachibana, E., Cheng, Y., and Zhu, T.: Dicarboxylic acids, ketocarboxylic acids, $\alpha$-dicarbonyls, fatty acids, and benzoic acid in urban aerosols collected during the 2006 Campaign of Air Quality Research in Beijing (CAREBeijing-2006), J. Geophys. Res.-Atmos., 115, D19312, https://doi.org/10.1029/2009JD013304, 2010.

Hyttinen, N., Kupiainen-Määttä, O., Rissanen, M. P., Muuronen, M., Ehn, M., and Kurtén, T.: Modeling the Charging of Highly Oxidized Cyclohexene Ozonolysis Products Using Nitrate-Based Chemical Ionization, J. Phys. Chem., A, 119, 6339-6345, 2015.

Isaacman-Vanwertz, G., Massoli, P., O’Brien, R., Lim, C., Franklin, J. P., Moss, J. A., Hunter, J. F., Nowak, J. B., Canagaratna, M. R., Misztal,P. K., Arata, C., Roscioli, J. R., Herndon, S. T., Onasch, T. B., Lambe, A. T., Jayne, J. T., Su, L., Knopf, D. A., Goldstein, A. H., Worsnop, D. R., and Kroll, J. H.: Chemical evolution of atmospheric organic carbon over multiple generations of oxidation, Nat. Chem., 10, 462-468, https://doi.org/10.1038/s41557018-0002-2, 2018

Jokinen, T., Sipilä, M., Junninen, H., Ehn, M., Lönn, G., Hakala, J., Petäjä, T., Mauldin III, R. L., Kulmala, M., and Worsnop, D. R.: Atmospheric sulphuric acid and neutral cluster measurements using CI-APi-TOF, Atmos. Chem. Phys., 12, 4117-4125, https://doi.org/10.5194/acp-12-4117-2012, 2012.

Jokinen, T., Sipilä, M., Richters, S., Kerminen, V. M., Paasonen, P., Stratmann, F., Worsnop, D., Kulmala, M., Ehn, M., Herrmann, H., and Berndt, T.: Rapid autoxidation forms highly oxidized $\mathrm{RO}_{2}$ radicals in the atmosphere, Angew. Chem. Int. Edit., 53, 14596-14600, https://doi.org/10.1002/anie.201408566, 2014.

Junninen, H., Ehn, M., Petäjä, T., Luosujärvi, L., Kotiaho, T., Kostiainen, R., Rohner, U., Gonin, M., Fuhrer, K., Kulmala, M., and Worsnop, D. R.: A high-resolution mass spectrometer to measure atmospheric ion composition, Atmos. Meas. Tech., 3, 10391053, https://doi.org/10.5194/amt-3-1039-2010, 2010.

Kawamura, K. and Kaplan, I. R.: Motor Exhaust Emissions as a Primary Source for Dicarboxylic Acids in Los Angeles Ambient Air, Environ. Sci. Technol., 21, 105-110, https://doi.org/10.1021/es00155a014, 1987.

Kerminen, V.-M., Paramonov, M., Anttila, T., Riipinen, I., Fountoukis, C., Korhonen, H., Asmi, E., Laakso, L., Lihavainen, H., Swietlicki, E., Svenningsson, B., Asmi, A., Pandis, S. N., Kulmala, M., and Petäjä, T.: Cloud condensation nuclei production associated with atmospheric nucleation: a synthesis based on existing literature and new results, Atmos. Chem. Phys., 12, 12037 12059, https://doi.org/10.5194/acp-12-12037-2012, 2012.

Khan, M., Cooke M, Utembe, S., Archibald A., Derwent, R., Jenkin, M., Morris, W., South, N., Hansen, J., Francisco, J., Percival, C., and Shallcross, D.: Global analysis of peroxy radicals and peroxy radical-water complexation using the STOCHEM-CRI 
global chemistry and transport model, Atmos. Environ., 106, 278-287, 2015.

Kirkby, J., Curtius, J., Almeida, J., Dunne, E., Duplissy, J., Ehrhart, S., Franchin, A., Gagné, S., Ickes, L., Kürten, A., Kupc, A., Metzger, A., Riccobono, F., Rondo, L., Schobesberger, S., Tsagkogeorgas, G., Wimmer, D., Amorim, A., Bianchi, F., Breitenlechner, M., David, A., Dommen, J., Downard, A., Ehn, M., Flagan, R. C., Haider, S., Hansel, A., Hauser, D., Jud, W., Junninen, H., Kreissl, F., Kvashin, A., Laaksonen, A., Lehtipalo, K., Lima, J., Lovejoy, E. R., Makhmutov, V., Mathot, S., Mikkilä, J., Minginette, P., Mogo, S., Nieminen, T., Onnela, A., Pereira, P., Petäjä, T., Schnitzhofer, R., Seinfeld, J. H., Sipilä, M., Stozhkov, Y., Stratmann, F., Tomé, A., Vanhanen, J., Viisanen, Y., Vrtala, A., Wagner, P. E., Walther, H., Weingartner, E., Wex, H., Winkler, P. M., Carslaw, K. S., Worsnop, D. R., Baltensperger, U., and Kulmala, M.: Role of sulphuric acid, ammonia and galactic cosmic rays in atmospheric aerosol nucleation, Nature, 476, 429-435, https://doi.org/10.1038/nature10343, 2011.

Kirkby, J., Duplissy, J., Sengupta, K., Frege, C., Gordon, H., Williamson, C., Heinritzi, M., Simon, M., Yan, C., Almeida, J., Trostl, J., Nieminen, T., Ortega, I. K., Wagner, R., Adamov, A., Amorim, A., Bernhammer, A. K., Bianchi, F., Breitenlechner, M., Brilke, S., Chen, X., Craven, J., Dias, A., Ehrhart, S., Flagan, R. C., Franchin, A., Fuchs, C., Guida, R., Hakala, J., Hoyle, C. R., Jokinen, T., Junninen, H., Kangasluoma, J., Kim, J., Krapf, M., Kurten, A., Laaksonen, A., Lehtipalo, K., Makhmutov, V., Mathot, S., Molteni, U., Onnela, A., Perakyla, O., Piel, F., Petaja, T., Praplan, A. P., Pringle, K., Rap, A., Richards, N. A., Riipinen, I., Rissanen, M. P., Rondo, L., Sarnela, N., Schobesberger, S., Scott, C. E., Seinfeld, J. H., Sipila, M., Steiner, G., Stozhkov, Y., Stratmann, F., Tomé, A., Virtanen, A., Vogel, A. L., Wagner, A. C., Wagner, P. E., Weingartner, E., Wimmer, D., Winkler, P. M., Ye, P., Zhang, X., Hansel, A., Dommen, J., Donahue, N. M., Worsnop, D. R., Baltensperger, U., Kulmala, M., Carslaw, K. S., and Curtius, J.: Ion-induced nucleation of pure biogenic particles, Nature, 533, 521-526, https://doi.org/10.1038/nature17953, 2016.

Kroll, J. H., Donahue, N. M., Jimenez, J. L., Kessler, S. H., Canagaratna, M. R., Wilson, K. R., Altieri, K. E., Mazzoleni, L. R., Wozniak, A. S., Bluhm, H., Mysak, E. R., Smith, J. D., Kolb, C. E., and Worsnop, D. R.: Carbon oxidation state as a metric for describing the chemistry of atmospheric organic aerosol, Nat. Chem., 3, 133-139, https://doi.org/10.1038/nchem.948, 2011.

Kulmala, M., Petäjä, T., Mönkkönen, P., Koponen, I. K., Dal Maso, M., Aalto, P. P., Lehtinen, K. E. J., and Kerminen, V.-M.: On the growth of nucleation mode particles: source rates of condensable vapor in polluted and clean environments, Atmos. Chem. Phys., 5, 409-416, https://doi.org/10.5194/acp-5-409-2005, 2005.

Kulmala, M., Petäjä, T., Nieminen, T., Sipilä, M., Manninen, H. E., Lehtipalo, K., Dal Maso, M., Aalto, P. P., Junninen, H., Paasonen, P.,Riipinen, I., Lehtinen, K. E. J., Laaksonen, A., and Kerminen, V.-M.: Measurement of the nucleation of atmospheric aerosol particles, Nat. Protoc., 7, 1651-1667, https://doi.org/10.1038/nprot.2012.091, 2012.

Kürten, A., Rondo, L., Ehrhart, S., and Curtius, J.: Calibration of a chemical ionization mass spectrometer for the measurement of gaseous sulfuric acid, J. Phys. Chem., A, 116, 6375-6386, 2012.

Kurtén, T., Rissanen, M. P., Mackeprang, K., Thornton, J. A., Hyttinen, N., Jørgensen, S., Ehn, M., and Kjaergaard, H. G.: Com- putational Study of Hydrogen Shifts and Ring-Opening Mechanisms in $\alpha$-Pinene Ozonolysis Products, J. Phys. Chem., A, 119 , 11366-11375, 2015.

Kurtén, T., Tiusanen, K., Roldin, P., Rissanen, M., Luy, J. N., Boy, M., Ehn, M., and Donahue, N.: $\alpha$-Pinene autoxidation products may not have extremely low saturation vapor pressures despite high O : C ratios, J. Phys. Chem., A, 120, 2569-2582, 2016.

Larriba, C., Hogan, C. J., Attoui, M., Borrajo, R., Garcia, J. F., and De La Mora, J. F.: The mobility-volume relationship below $3.0 \mathrm{~nm}$ examined by tandem mobility-mass measurement, Aerosol Sci. Tech., 45, 453-467, 2011.

Lee, B. H., Mohr, C., Lopez-Hilfiker, F. D., Lutz, A., Hallquist, M., Lee, L., Romer, P., Cohen, R. C., Iyer, S., Kurtén, T., Hu, W., Day, D. A., Campuzano-Jost, P., Jimenez, J. L., Xu, L., Ng, N. L., Guo, H., Weber, R. J., Wild, R. J., Brown, S. S., Koss, A., de Gouw, J., Olson, K., Goldstein, A. H., Seco, R., Kim, S., McAvey, K., Shepson, P. B., Starn, T., Baumann, K., Edgerton, E. S., Liu, J., Shilling, J. E., Miller, D. O., Brune, W., Schobesberger, S., D'Ambro, E. L., and Thornton, J. A.: Highly functionalized organic nitrates in the southeast United States: Contribution to secondary organic aerosol and reactive nitrogen budgets, P. Natl. Acad. Sci. USA, 113, 1516-1521, 2016.

Massoli, P., Stark, H., Canagaratna, M. R., Krechmer, J. E., Xu, L., Ng, N. L., Mauldin, R. L., Yan, C., Kimmel, J., Misztal, P. K., Jimenez, J. L., Jayne, J. T., and Worsnop, D. R.: Ambient Measurements of Highly Oxidized Gas-Phase Molecules during the Southern Oxidant and Aerosol Study (SOAS) 2013, ACS Earth Space Chem., 2, 653-672, 2018.

McMurry, P. H., Shan Woo, K., Weber, R., Chen, D.-R., and Pui, D. Y. H.: Size distributions of 3-10 nm atmospheric particles: implications for nucleation mechanisms, Philos. T. Roy. Soc. A, 358, 2625-2642, 2000.

Miller, M. R., Raftis, J. B., Langrish, J. P., McLean, S. G., Samutrtai, P., Connell, S. P., Wilson, S., Vesey, A. T., Fokkens, P. H., Boere, A. J. F., Krystek, P., Campbell, C. J., Hadoke, P. W., Donaldson, K., Cassee, F. R., Newby, D. E., Duffin, R., and Mills, N. L.: Inhaled nanoparticles accumulate at sites of vascular disease, ACS Nano, 11, 4542-4552, 2017.

Møller, K. H., Tram, C. M., and Kjaergaard, H. G.: Side-by-Side Comparison of Hydroperoxide and Corresponding Alcohol as HydrogenBond Donors, J. Phys. Chem. A, 121, 2951-2959, 2017.

Molteni, U., Bianchi, F., Klein, F., El Haddad, I., Frege, C., Rossi, M. J., Dommen, J., and Baltensperger, U.: Formation of highly oxygenated organic molecules from aromatic compounds, Atmos. Chem. Phys., 18, 1909-1921, https://doi.org/10.5194/acp18-1909-2018, 2018.

Mutzel, A., Poulain, L., Berndt, T., Iinuma, Y., Rodigast, M., Böge, O., Richters, S., Spindler, G., Sipila, M., Jokinen, T., Kulmala, M., and Herrmann, H.: Highly oxidized multifunctional organic compounds observed in tropospheric particles: A field and laboratory study, Environ. Sci. Technol., 49, 7754-7761, 2015.

Myllys, N., Olenius, T., Kurtén, T., Vehkamäki, H., Riipinen, I., and Elm, J.: Effect of Bisulfate, Ammonia, and Ammonium on the Clustering of Organic Acids and Sulfuric Acid, J. Phys. Chem. A, 121, 4812-4824, 2017.

Narukawa, M., Kawamura, K., Takeuchi, N., and Nakajima, T.: Distribution of dicarboxylic acids and carbon isotopic ratios in 
aerosols from 1997 Indonesian forest fires, Geophys. Res. Lett., 26, 3101-3104, 1999.

Penner, J. E., Xu, L., and Wang, M.: Satellite methods underestimate indirect climate forcing by aerosols, P. Natl. Acad. Sci. USA, 108, 13404-13408, 2011.

Praske, E., Otkjær, R. V., Crounse, J. D., Hethcox, J. C., Stoltz, B. M., Kjaergaard, H. G., and Wennberg, P. O.: Atmospheric autoxidation is increasingly important in urban and suburban North America, P. Natl. Acad. Sci. USA, 115, 64-69, 2018.

Qi, X., Ding, A., Roldin, P., Xu, Z., Zhou, P., Sarnela, N., Nie, W., Huang, X., Rusanen, A., Ehn, M., Rissanen, M. P., Petäjä, T., Kulmala, M., and Boy, M.: Modelling studies of HOMs and their contributions to new particle formation and growth: comparison of boreal forest in Finland and a polluted environment in China, Atmos. Chem. Phys., 18, 11779-11791, https://doi.org/10.5194/acp-18-11779-2018, 2018.

Quéléver, L. L. J., Kristensen, K., Normann Jensen, L., Rosati, B., Teiwes, R., Daellenbach, K. R., Peräkylä, O., Roldin, P., Bossi, R., Pedersen, H. B., Glasius, M., Bilde, M., and Ehn, M.: Effect of temperature on the formation of highly oxygenated organic molecules (HOMs) from alpha-pinene ozonolysis, Atmos. Chem. Phys., 19, 7609-7625, https://doi.org/10.5194/acp19-7609-2019, 2019.

Riccobono, F., Schobesberger, S., Scott, C., Dommen, J., Ortega, I., Rondo, L., Almeida, J., Amorim, A., Bianchi, F., Breitenlechner, M., David, A., Downard, A., Dunne, E., Duplissy, J., Ehrhart, S., Flagan, R., Franchin, A., Hansel, A., Junninen, H., Kajos, M., Keskinen, H., Kupc, A., Kürten, A., Kvashin, A., Laaksonen, A., Lehtipalo, K., Makhmutov, V., Mathot, S., Nieminen, T., Onnela, A., Petäjä, T., Praplan, A., Santos, F., Schallhart, S., Seinfeld, J., Sipilä, M., Van Spracklen, D., Stozhkov, Y., Stratmann, F., Tomé, A., Tsagkogeorgas, G., Vaattovaara, P., Viisanen, Y., Vrtala, A., Wagner, P., Weingartner, E., Wex, H., Wimmer, D., Carslaw, K., Curtius, J., Donahue, N., Kirkby, J., Kulmala, M., Worsnop, D., and Baltensperger, U.: Oxidation products of biogenic emissions contribute to nucleation of atmospheric particles, Science, 344, 717-721, 2014.

Rissanen, M. P.: $\mathrm{NO}_{2}$ Suppression of AutoxidationInhibition of Gas-Phase Highly Oxidized Dimer Product Formation, ACS Earth Space Chem., 2, 1211-1219, https://doi.org/10.1021/acsearthspacechem.8b00123, 2018.

Rissanen, M. P., Kurtén, T., Sipilä, M., Thornton, J. A., Kangasluoma, J., Sarnela, N., Junninen, H., Jørgensen, S., Schallhart, S., Kajos, M. K., Taipale, R., Springer, M., Mentel, T. F., Ruuskanen, T., Petäjä, T., Worsnop, D. R., Kjaergaard, H. G., and Ehn, M.: The formation of highly oxidized multifunctional products in the ozonolysis of cyclohexene, J. Am. Chem. Soc., 136, 1559615606, 2014.

Rose, C., Zha, Q., Dada, L., Yan, C., Lehtipalo, K., Junninen, H., Mazon, S. B., Jokinen, T., Sarnela, N., Sipilä, M., Petäjä, T., Kerminen, V.-M., Bianchi, F., and Kulmala, M.: Observations of biogenic ion-induced cluster formation in the atmosphere, Sci. Adv., 4, eaar5218, https://doi.org/10.1126/sciadv.aar5218, 2018.

Schobesberger, S., Junninen, H., Bianchi, F., Lönn, G., Ehn, M., Lehtipalo, K., Dommen, J., Ehrhart, S., Ortega, I. K., Franchin, A., Nieminen, T., Riccobono, F., Hutterli, M., Duplissy, J., Almeida, J., Amorim, A., Breitenlechner, M., Downard, A. J., Dunne, E. M., Flagan, R. C., Kajos, M., Keskinen, H., Kirkby, J., Kupc, A., Kürten, A., Kurtén, T., Laaksonen, A., Mathot, S.,
Onnela, A., Praplan, A. P., Rondo, L., Santos, F. D., Schallhart, S., Schnitzhofer, R., Sipilä, M., Tomé, A., Tsagkogeorgas, G., Vehkamäki, H., Wimmer, D., Baltensperger, U., Carslaw, K. S., Curtius, J., Hansel, A., Petäjä, T., Kulmala, M., Donahue, N. M., and Worsnop, D. R.: Molecular understanding of atmospheric particle formation from sulfuric acid and large oxidized organic molecules., P. Natl. Acad. Sci. USA, 110, 17223-17228, 2013.

Shi, J. P., Evans, D. E., Khan, A. A., and Harrison, R. M.: Sources and concentration of nanoparticles $(<10 \mathrm{~nm}$ diameter $)$ in the urban atmosphere, Atmos. Environ., 35, 1193-1202, 2001.

Shi, Z., Vu, T., Kotthaus, S., Harrison, R. M., Grimmond, S., Yue, S., Zhu, T., Lee, J., Han, Y., Demuzere, M., Dunmore, R. E., Ren, L., Liu, D., Wang, Y., Wild, O., Allan, J., Acton, W. J., Barlow, J., Barratt, B., Beddows, D., Bloss, W. J., Calzolai, G., Carruthers, D., Carslaw, D. C., Chan, Q., Chatzidiakou, L., Chen, Y., Crilley, L., Coe, H., Dai, T., Doherty, R., Duan, F., Fu, P., Ge, B., Ge, M., Guan, D., Hamilton, J. F., He, K., Heal, M., Heard, D., Hewitt, C. N., Hollaway, M., Hu, M., Ji, D., Jiang, X., Jones, R., Kalberer, M., Kelly, F. J., Kramer, L., Langford, B., Lin, C., Lewis, A. C., Li, J., Li, W., Liu, H., Liu, J., Loh, M., Lu, K., Lucarelli, F., Mann, G., McFiggans, G., Miller, M. R., Mills, G., Monk, P., Nemitz, E., O’Connor, F., Ouyang, B., Palmer, P. I., Percival, C., Popoola, O., Reeves, C., Rickard, A. R., Shao, L., Shi, G., Spracklen, D., Stevenson, D., Sun, Y., Sun, Z., Tao, S., Tong, S., Wang, Q., Wang, W., Wang, X., Wang, X., Wang, Z., Wei, L., Whalley, L., Wu, X., Wu, Z., Xie, P., Yang, F., Zhang, Q., Zhang, Y., Zhang, Y., and Zheng, M.: Introduction to the special issue "In-depth study of air pollution sources and processes within Beijing and its surrounding region (APHH-Beijing)", Atmos. Chem. Phys., 19, 7519-7546, https://doi.org/10.5194/acp19-7519-2019, 2019.

Stolzenburg, D, Fischer, L., Vogel, A., Heinritzi, M., Schervish, M., Simon, M., Wagner, A., Dada, L., Ahonen, L., Amorim, A., Baccarini, A., Bauer, P., Baumgartner, B., Bergen, A., Bianchi, F., Breitenlechner, M., Brilke, S., Buenrostro Mazon, S., Chen, D., Dias, A., Draper, D., Duplissy, J., El Haddad, I., Finkenzeller, H., Frege, C., Fuchs, C., Garmash, O., Gordon, H., He, X., Helm, J., Hofbauer, V., Hoyle, C., Kim, C., Kirkby, J., Kontkanen, J., Kürten, A., Lampilahti, J., Lawler, M., Lehtipalo, K., Leiminger, M., Mai, H., Mathot, S., Mentler, B., Molteni, U., Nie, W., Nieminen, T., Nowak, J., Ojdanic, A., Onnela, A., Passananti, M., Petäjä, T., Quéléver, L., Rissanen, M., Sarnela, N., Schallhart, S., Tauber, C., Tomé, A., Wagner, R., Wang, M., Weitz, L., Wimmer, D., Xiao, M., Yan, C., Ye, P., Zha, Q., Baltensperger, U., Curtius, J., Dommen, J., Flagan, R., Kulmala, M., Smith, J., Worsnop, D., Hansel, A., Donahue, N., and Winkler, P.: Rapid growth of organic aerosol nanoparticles over a wide tropospheric temperature range, P. Natl. Acad. Sci. USA, 115, 9122-9127, 2018.

Tammet, H.: Size and mobility of nanometer particles, clusters and ions, J. Aerosol Sci., 26, 459-475, 1995.

Tomasi, C., Fuzzi, S., and Kokhanovsky, A.: Atmospheric Aerosols: Life Cycles and Effects on Air Quality and Climate, John Wiley \& Sons, Weinheim, Germany, 2017.

Tröstl, J., Chuang, W. K., Gordon, H., Heinritzi, M., Yan, C., Molteni, U., Ahlm, L., Frege, C., Bianchi, F., Wagner, R., Simon, M., Lehtipalo, K., Williamson, C., Craven, J. S., Duplissy, J., Adamov, A., Almeida, J., Bernhammer, A. K., Breitenlechner, M., Brilke, S., Dias, A., Ehrhart, S., Flagan, R. C., Franchin, A., Fuchs, C., Guida, R., Gysel, M., Hansel, A., 
Hoyle, C. R., Jokinen, T., Junninen, H., Kangasluoma, J., Keskinen, H., Kim, J., Krapf, M., Kürten, A., Laaksonen, A., Lawler, M., Leiminger, M., Mathot, S., Möhler, O., Nieminen, T., Onnela, A., Petäjä, T., Piel, F. M., Miettinen, P., Rissanen, M. P., Rondo, L., Sarnela, N., Schobesberger, S., Sengupta, K., Sipilä, M., Smith, J. N., Steiner, G., Tomè, A., Virtanen, A., Wagner, A. C., Weingartner, E., Wimmer, D., Winkler, P. M., Ye, P., Carslaw, K. S., Curtius, J., Dommen, J., Kirkby, J., Kulmala, M., Riipinen, I., Worsnop, D. R., Donahue, N. M., and Baltensperger, U.: The role of low-volatility organic compounds in initial particle growth in the atmosphere, Nature, 533, 527-531, https://doi.org/10.1038/nature18271, 2016.

Wang, S., Wu, R., Berndt, T., Ehn, M., and Wang, L.: Formation of Highly Oxidized Radicals and Multifunctional Products from the Atmospheric Oxidation of Alkylbenzenes, Environ. Sci. Techn., 51, 8442-8449, 2017.

Wang, Z., Wu, Z., Yue, D., Shang, D., Guo, S., Sun, J., Ding, A., Wang, L., Jiang, J., Guo, H., Gao, J., Cheung, H. C., Morawska, L., Keywood, M., and Hu, M.: New particle formation in China: Current knowledge and further directions, Sci. Total Environ., 577, 258-266, 2016.

Wiedensohler, A., Cheng, Y. F., Nowak, A., Wehner, B., Achtelt, P., Berghof, M., Birmili, W., Wu, Z. J., Hu, M., Zhu, T., Takegawa, N., Kita, K., Kondo, Y., Lou, S. R., Hofeumahaus, A., Holland, F., Wahner, A., Gunthe, S. S., Rose, D., Su, H., and Pöschl, U.: Rapid aerosol particle growth and increase of cloud condensation nucleus activity by secondary aerosol formation and condensation: A case study for regionalair pollution in northeastern China, J. Geophys. Res.-Atmos., 114, 1-13, https://doi.org/10.1029/2008JD010884, 2009.

Wu, Z., Hu, M., Liu, S., Wehner, B., Bauer, S., Massling, A., Wiedensohler, A., Petäjä, T., Dal Maso, M., and Kulmala, M.: New particle formation in Beijing, China: Statistical analysis of a 1-year data set, J. Geophys. Res.-Atmos., 112, D09209, https://doi.org/10.1029/2006JD007406, 2007.

Wu, Z., Hu, M., Lin, P., Liu, S., Wehner, B., and Wiedensohler, A.: Particle number size distribution in the urban atmosphere of Beijing, China, Atmos. Environ., 42, 7967-7980, 2008.

Wu, Z., Ma, N., Größ, J., Kecorius, S., Lu, K., Shang, D., Wang, Y., Wu, Y., Zeng, L., Hu, M., Wiedensohler, A., and Zhang, Y.: Thermodynamic properties of nanoparticles during new particle formation events in the atmosphere of North China Plain, Atmos. Res., 188, 55-63, 2017.
Xiong, F., McAvey, K. M., Pratt, K. A., Groff, C. J., Hostetler, M. A., Lipton, M. A., Starn, T. K., Seeley, J. V., Bertman, S. B., Teng, A. P., Crounse, J. D., Nguyen, T. B., Wennberg, P. O., Misztal, P. K., Goldstein, A. H., Guenther, A. B., Koss, A. R., Olson, K. F., de Gouw, J. A., Baumann, K., Edgerton, E. S., Feiner, P. A., Zhang, L., Miller, D. O., Brune, W. H., and Shepson, P. B.: Observation of isoprene hydroxynitrates in the southeastern United States and implications for the fate of $\mathrm{NO}_{x}$, Atmos. Chem. Phys., 15, 11257-11272, https://doi.org/10.5194/acp-1511257-2015, 2015.

Yan, C., Nie, W., Äijälä, M., Rissanen, M. P., Canagaratna, M. R., Massoli, P., Junninen, H., Jokinen, T., Sarnela, N., Häme, S. A. K., Schobesberger, S., Canonaco, F., Yao, L., Prévôt, A. S. H., Petäjä, T., Kulmala, M., Sipilä, M., Worsnop, D. R., and Ehn, M.: Source characterization of highly oxidized multifunctional compounds in a boreal forest environment using positive matrix factorization, Atmos. Chem. Phys., 16, 12715-12731, https://doi.org/10.5194/acp-16-12715-2016, 2016.

Yao, L., Garmash, O., Bianchi, F., Zheng, J., Yan, C., Kontkanen, J., Junninen, H., Mazon, S. B., Ehn, M., Paasonen, P., Sipilä, M., Wang, M., Wang, X., Xiao, S., Chen, H., Lu, Y., Zhang, B., Wang, D., Fu, Q., Geng, F., Li, L., Wang, H., Qiao, L., Yang, X., Chen, J., Kerminen, V. M., Petäjä, T., Worsnop, D. R., Kulmala, M., and Wang, L.: Atmospheric new particle formation from sulfuric acid and amines in a Chinese megacity, Science, 361, 278281, 2018.

Yu, F. and Luo, G.: Simulation of particle size distribution with a global aerosol model: contribution of nucleation to aerosol and CCN number concentrations, Atmos. Chem. Phys., 9, 76917710, https://doi.org/10.5194/acp-9-7691-2009, 2009.

Yue, D. L., Hu, M., Zhang, R. Y., Wu, Z. J., Su, H., Wang, Z. B., Peng, J. F., He, L. Y., Huang, X. F., Gong, Y. G., and Wiedensohler, A.: Potential contribution of new particle formation to cloud condensation nuclei in Beijing, Atmos. Environ., 45, 6070-6077, 2011.

Zhao, Y., Wingen, L. M., Perraud, V., Greaves, J., and FinlaysonPitts, B. J.: Role of the reaction of stabilized Criegee intermediates with peroxy radicals in particle formation and growth in air, Phys. Chem. Chem. Phys., 17, 12500-12514, 2015. 